\title{
The Role of Work-Life Balance and Worker Scheduling Flexibility in Predicting Global Comparative Job Satisfaction
}

Maureen Snow Andrade

USA

Jonathan H Westover

USA

Bernd A Kupka

USA

Received: Feb. 20, 2019 Accepted: Mar. 13, 2019 Online published: Apr. 2, 2019

doi:10.5296/ijhrs.v9i2.14375 URL: https://doi.org/10.5296/ijhrs.v9i2.14375

\begin{abstract}
Prior research has indicated that the nature of work has changed dramatically in recent years in response to economic shifts and an increasingly global economy. In part, this shift has resulted in a greater efficacy of various work-life balance and worker schedule flexibility elements in the experiences of employees in the workplace. However, little is known about the overall comparative quality of work and job satisfaction around the world in response to a shifting and increasingly interconnected global economy. In this study, we use non-panel longitudinal data from the most recent wave of the International Social Survey Program (Work Orientations IV, 2015) to conduct an exploratory comparative analysis of the impact of various workplace conditions, job characteristics, and employee attitudes in relation to comparative job satisfaction across the globe, with a special focus on the role of work-life balance and worker scheduling flexibility. Employees across the globe respond quite differently to work scenarios, which poses challenges for companies operating in multiple countries, requires adjustments to human resource practices to optimize performance levels of employees and reduce turnover expenses, and should caution managers to scrutinize their procedures to adjust to new demands in the workplace. This study adds value by making global comparisons of various workplace factors and their impact on job satisfaction using a
\end{abstract}


database reflecting practices in 37 countries.

Keywords: work-life balance, global comparisons, job satisfaction, scheduling flexibility

\section{Introduction}

Since Happock's seminal work on the topic in 1935, job satisfaction has continued to generate interest across disciplines, from psychology (Argyle, 1989) and sociology (Kalleberg \& Loscocco, 1983; Hodson, 2002), to economics (Freeman, 1978; Hamermesh, 2001), management sciences (Hunt \& Saul, 1975), and public administration (Wright \& Kim, 2004; Jung, Moon, \& Hahm., 2007). The interest in job satisfaction, as much for researchers as for practitioners, is due to several reasons. Satisfied workers are more productive (Appelbaum \& Kamal, 2000), deliver higher quality of work (Tietjen \& Myers, 1998), and improve a firm's competitiveness and success (Garrido, Perez, \& Anton, 2005). Conversely, unsatisfied workers are more frequently late for work, absent from work, and motivated to leave the firm (Blau, 1994; Lee, 1998).

Additionally, a variety of literature across academic disciplines indicates that the nature of work has changed dramatically in recent years in response to economic shifts and an increasingly global economy (see Westover, 2008a, 2008b; Westover, 2009; Westover, 2010a, 2010b; Westover \& Taylor, 2010; Taylor \& Westover, 2011; Westover, 2011; Westover, 2012a, 2012b, 2012c, 2012d; Westover, 2013a, 2013b; Westover, Doxey, Trista, \& Spencer, 2013; Westover, in press-a, in press-b). However, there is little known about the how, why, when, and influenced by whom and what comparative shifts of the overall quality of work and job satisfaction over the last decades and across national contexts have occurred.

We use the International Social Survey Program Work Orientations data from 2015 to explore (1) the general differences in workplace conditions and employee attitudes across the globe, (2) the causes for the cross-national differences that do exist, and (3) specifically the role of work-life balance and worker scheduling flexibility in predicting global comparative job satisfaction.

\section{A Brief Review of the Work-Life Balance and Worker Scheduling Flexibility Literature}

Only about a third of employees in the United States are engaged in their work (Gallup, Inc., 2017). Approximately half of sampled respondents indicated they were just putting in time (practiced presenteeism), and the remainder were dissatisfied to the point of adopting counterproductive work behaviors (Gallup, Inc., 2017; Iliescu, Ispas, Sulea, \& Ilie, 2017). Although the impact of dissatisfaction on absenteeism is only moderate (Ybema, Smulders, \& Bongers, 2010), lowered productivity is significant (O'Keefe, 2014) as is turnover (Chen, Ployhart, Thomas, Anderson, \& Bliese, 2011; Griffeth, Hom, \& Gaertner, 2000). In contrast, employees who demonstrate purpose and commitment to their work exhibit increased satisfaction and productivity (Judge, Thoresen, Bono, \& Patton, 2001).

A contributing factor to job satisfaction is work-life balance. Work-life balance describes the interaction and impact of work and family responsibilities with satisfaction in either or both 
areas as a "core consequence" (Brough, Tims, O’Driscoll, Kalliath, Siu, Sit, \& Lo, 2014, p. 2725). However, outcomes can be both positive or negative depending on whether balance or imbalance is present. Outcomes encompass work-, non-work-, and stress-related variables, such as job satisfaction, turnover, absenteeism, and performance; marital, family, and life satisfaction; and stress, burnout, and substance abuse across the three categories (Allen, Herst, Bruck, \& Sutton, 2000). Work-life imbalance is associated with high work demands, turnover intentions, and psychological strain, and balance with family and job satisfaction (Brough et al., 2014).

Cegarra-Leiva, Sanchez-Vidal, and Cegarra-Navarro (2012) point out that "research on WLB needs to be considered in the context of the national culture in which the study is conducted, because there are social, economic and cultural factors that impact on the work and family conflict experiences of workers and on the availability and use of WLB practices in organizations" (p. 95). The authors point out the examples of Finland, Norway, and Germany who experience lower levels of employee imbalance in contrast to other European Union countries. They observe that employers these countries offer more family-friendly work policies. In comparison, Spanish employees see less family-advantageous work environments with long work days and limited part-time work arrangements. Our research effort tries to answer this call for action and compares WLB outcomes across the globe.

\subsection{Schedule Flexibility, Work-Life Balance, and Job Satisfaction}

Schedule flexibility in the workplace can ameliorate work-life imbalance. It encompasses flex time (modified arrival and departure times) and flex place (work at home, telecommuting, compressed workweeks), work time choices (when and how people work), reduced time (part-time or part-year), caregiving leave (for children or elderly family members), and time off (scheduled absences and unplanned occasions) (Matos, Galinsky, \& Bond, 2017). Such arrangements can be instituted through formal employer policy or through individual arrangements between employee and supervisor (Carlson, Grzywacz, \& Kacmar, 2010).

Schedule flexibility "creates the opportunity to minimize work-family conflict, promote work-family enrichment and improve functioning and performance at work and home" (Carlson et al., 2010, p. 331). In contrast, work-family conflict - the incompatibility of a person's work and home roles - negatively affects the way one performs in both domains (Carlson et al., 2010; Greenhaus \& Beutell, 1985; Kreiner, Hollensbe, \& Sheep, 2009), and decreases job and family satisfaction (Michel \& Michel, 2012; Pattusamy \& Jacob, 2017).

Flexible schedules have been correlated with increased job commitment, work satisfaction and performance, organizational citizenship behaviors, improved group dynamics, decreased turnover intent, home-family enrichment, home satisfaction, and reduced work-home conflict (Allen, 2001; Carlson et al., 2010; Eaton, 2003; Jones, Scovile, Hill, Childs, Leishman, \& Nally, 2008; Kossek \& Oseki, 1998; Roehling, Roehling, \& Moen, 2001; Van Dyne, Kossek, $\&$ Lobel, 2007). Flex time (the ability to determine arrival and departure times), specifically, and compressed work schedules (more hours per day but fewer days per week), have been associated with perceptions of work-home enrichment, and, in turn, with increased job satisfaction and decreased turnover intentions (McNall, Masuda, \& Nicklin, 2010). Similarly, 
the perception of a flexible work environment (e.g., the ability to physically leave the work place for family or personal reasons) has been associated with work-home enrichment (Daniel \& Sonnentag, 2016).

However, findings have been inconsistent. A study of Canadian government, healthcare, and education sector employees found that traditional 9-5 and compressed work week schedules were associated with reduced work-family conflict, yet flex time and telework (working from home) resulted in higher levels of work-family conflict (Higgins, Duxbury, \& Julien, 2014). The researchers postulated that this may be due to employees feeling that they can stop work at the end of the day when they are on a traditional schedule, whereas boundaries are more permeable for those on a flexible schedule, particularly when working from home; thus, the latter may work longer hours and experience more work-family conflict.

Similarly, in another study, compressed work weeks for federal government employees were associated with decreased quality of daily family time and parents sometimes not seeing children at all some days of the week (Saltzstein, Ting, \& Saltzstein, 2001). Others have found that compressed work weeks decreased work-family conflict but had no impact on job satisfaction (Facer \& Wadsworth, 2008). These studies suggest the need to differentiate among types of schedule flexibility and the populations using them.

In terms of job satisfaction and flexible scheduling, 62\% of both high- and low-wage employees reported increased levels of satisfaction when flexible options were high (Matos \& Galinsky, 2011). Indeed, higher flexibility is associated with greater percentages of employees reporting job satisfaction across sectors and company sizes (Matos \& Galinsky, 2011). Self-scheduling for nurses in Canada, aimed at flexible work hours, for example, improved morale and job satisfaction (Koning, 2014). In spite of $79 \%$ of employees indicating they would like more flexible scheduling options, however, the number of workplaces allowing time off during the workday for family or personal matters decreased from $85 \%$ to $81 \%$ from 2012 to 2016 with little change in the growth of flexible scheduling options during that time period (Matos et al, 2017).

Additionally, leave provisions related to family needs, such as caring for dependents, sudden and serious illnesses, and giving birth, can be inadequate even when provided, and result in imbalance and stress (Brough, O'Driscoll, \& Briggs, 2009; Gatrell, Burnett, Cooper, \& Sparrow, 2013). Of employees who have access to flexible schedules, the majority who use them are women (Carlson et al., 2010; Matos et al., 2017). As such, they benefit from flexible work schedules that offer the means to balance competing demands. Employees experiencing work-family conflict resulting from inadequate leave provisions may seek family-friendly employment elsewhere (Brough, Holt, Bauld, Biggs, \& Ryan, 2008; O’Driscoll, Brough, \& Haar, 2011). Indeed, the ability to work from home influences employee decisions to accept a new position or leave a current position (Gallup, Inc., 2017). In the same Gallup study, 51\% of employees said they would leave their current job for one with more flexible scheduling, $35 \%$ would change jobs to one where they could work at home full time, and 37\% would change jobs for one in which they could work at home part time (Gallup, Inc., 2017). 


\subsection{Career and Home Integration}

The interdependencies of work and home are considered by both men and women as they make career decisions. Home is defined as nonwork involvements such as relationships with family and friends, and community, leisure, or self-development pursuits (Greenhaus \& Kossek, 2014). Home-career interference, or the degree to which people view their home responsibilities as a constraint to current or future careers, has been correlated with lowered career goal self-efficacy and career satisfaction (Schooreel, Shockley, \& Verbruggen, 2017). Employees who perceived reduced organization support for further training also experienced less career goal self-efficacy and satisfaction due to the belief they were not developing needed skills for advancement. In another study, the satisfaction and expectations for advancement of dual-earner couples were impacted by home-work interference, such as turning down career opportunities that required travel or relocation (Becker \& Moen, 1999). Couples implemented family-level scaling back strategies to manage career interference but needed more workplace flexibility. Home-career interference appears to negatively impact satisfaction with one's current career, create doubts about the likelihood of achieving desired career aspirations in the future, and result in family-level scaling back strategies.

Job satisfaction can spill into and enrich family life while the opposite is also true - satisfaction at home can have a positive impact on work (Brough, 2014; Carlson et al., 2010; Greenhaus \& Powell, 2006; Hanson, Hammer, \& Colton, 2006; Voydanoff, 2005). Referred to as work-family enrichment, this factor describes how "experiences in one role improve the quality of life in the other role" (Greenhaus \& Powell, 2006, p. 73). Segmenters prefer to separate work and home while integrators prefer to blend the two domains (Kreiner et al., 2009). Integrators are more likely to work longer hours and experience more work-family conflict.

Flexible workplace boundaries refer to the ability to leave work to take care of family responsibilities while permeability refers to physically being in one role (work or family) while mentally in another (Daniel \& Sonnentag, 2016). Employees have different preferences for integration or separation across these dimensions. Those who preferred to integrate work into the family domain experienced greater work-home enrichment. Similarly, those who perceived time flexibility in the workplace experienced greater work-home enrichment, which was related to job satisfaction (Daniel \& Sonnentag, 2016).

A longitudinal study of university employees found that those with highly integrated work and family roles experienced more positive and negative spillover of daily job satisfaction at home (Ilies, Wilson, \& Wagner, 2009). Similarly, integrating work into family life, particularly sharing successful work experiences at home, positively impacted work-home enrichment in a study of German employees with children at home (Daniel \& Sonnentag, 2016). Researchers studying bank employees in China found a positive correlation between daily work engagement and work-home enrichment when intrinsically motivated employees shared positive work experiences with spouses (Iles, Liu, Liu, \& Zheng, 2017). In another study, although incongruence between work and home reduced satisfaction in both realms, Episcopal parish priests implemented behavioral, communicative, temporal, and physical 


\section{Macrothink}

International Journal of Human Resource Studies

ISSN 2162-3058

2019, Vol. 9, No. 2

tactics to overcome this conflict (Kreiner et al., 2009). These studies illustrate how daily job experiences and satisfaction impact home life and vice versa, and how potential conflict can be successfully ameliorated.

This review has identified that employees and employers face various challenges and outcomes related to WLB. Imbalance has negative repercussions for individuals, families, and employers. Balance can be enhanced through flexible schedules as well as family-initiated strategies to address issues. Flex schedules have been predominantly effective in increasing job satisfaction and improving WLB. Employees want more flexibility and self-report its efficacy (Daniel \& Sonnentag, 2016; Matos \& Galinsky, 2011; McNall et al., 2010); however, findings have been mixed for some types of scheduling and in some contexts (Facer \& Wadsworth, 2008; Higgins et al., 2014; Saltzstein et al., 2001). Additionally, home-career interference negatively impacts career satisfaction and career goal self-efficacy leading to dissatisfaction in both home and work domains (Schooreel et al., 2017). Various forms of work-home enrichment, such as sharing positive work experiences in the home environment (Daniel \& Sonnentag, 2016; Ilies et al., 2009; Ilies et al., 2017), and strategies to ameliorate work-home conflict (Kreiner et al., 2009) and manage dual careers (Becker \& Moen, 1999) have been helpful in improving WLB.

\section{Theoretical Framework and Model}

To understand the drivers of job satisfaction, we have developed a theoretical model that synthesizes the literature to date in explaining the influences on the experiences of workers and their overall job satisfaction. While many studies have pointed to the importance of various intrinsic, extrinsic, and work relations variables, this model also includes important contextual factors such as control variables for organizational and job characteristics. Additionally, and most germane to this current research, we include a range of work-life balance variables. 


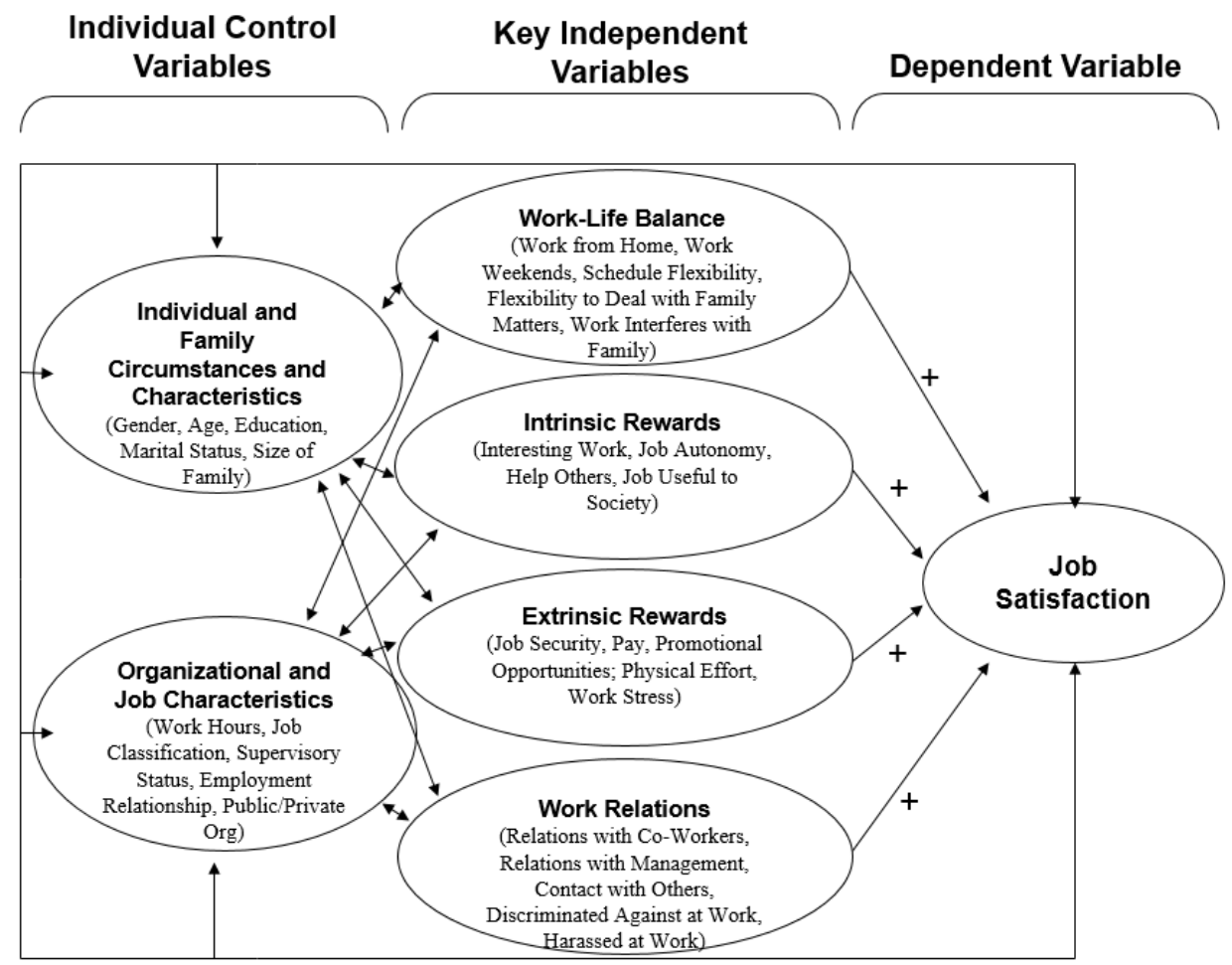

Figure 1. Drivers of Job Satisfaction

\section{Research Design and Methodology}

The following section will outline the main hypotheses of this research, including: (1) International Differences in Job Satisfaction and (2) Job satisfaction and Work-Life Balance.

\subsection{International Differences in Job Satisfaction and its Determinants}

Based on a growing body of comparative international job satisfaction literature, there is the likelihood that the national work context can impact on the workplace and the nature of work, which can in turn affect job satisfaction. Therefore, the levels of job satisfaction and its determinants of the respondents from the 37 countries are expected to differ cross-nationally, resulting in the following hypothesis:

H1a: There are statistically significant cross-national differences in the levels of job satisfaction across countries.

H1a: There are statistically significant cross-national differences in the determinants of job satisfaction across countries

\subsection{Job Satisfaction and Work-Life Balance}

The limited literature examining the impacts of work-life balance and work scheduling flexibility on job satisfaction suggest the following hypothesis:

H2a: Work from home positively impacts job satisfaction across nations.

$\mathrm{H} 2 \mathrm{~b}$ : Work on weekends negatively impacts job satisfaction across nations.

H2c: Schedule flexibility positively impacts job satisfaction across nations. 
H2d: Schedule flexibility to deal with family matters positively impacts job satisfaction across nations.

H3a: Work interfering with family negatively impacts job satisfaction across nations.

\subsection{Description of the Data}

We use non-panel longitudinal data from the 2015 wave of the International Social Survey Program (ISSP) Work Orientations Modules IV-various survey questions on job characteristics and job quality. The International Social Survey Program Work Orientations modules utilized a multistage stratified probability sample to collect the data for each of the various countries with a variety of eligible participants in each country's target population ${ }^{1}$. As noted in Table 1 and Figure 2 below, 37 countries participated in the 2015 wave. The Work Orientations module focuses on the areas of general attitudes toward work and leisure, work organization, and work content ${ }^{2}$. Variables of interest in the data collected by the International Social Survey Program are single-item indicators (i.e. with a single survey question for job satisfaction, interesting work, job autonomy, workplace relations, etc., on a Likert scale). For the purposes of this study, the units of analysis start with individuals within the separate sovereign nations. In addition to examining one large sample including all respondents from all participating countries, we examine a separate sample for each country to determine which job characteristics best predict job satisfaction in that particular country and then make cross-national comparisons.

\subsection{Operationalization of Variables}

We use Handel's (2005) job satisfaction model (based on Kalleberg's 1977 findings) for conducting a cross-national comparison of job satisfaction and the perceived importance of intrinsic and extrinsic job quality characteristic and work relations across countries (see also Spector 1997; Souza-Poza \& Souza-Poza 2000; de Bustillo Llorente \& Macias 2005). Following the approach of Handel (2005), 10 intrinsic and extrinsic variables were available for all countries in the 2015 Work Orientations data and thus utilized for this study. Additionally, as can be seen in Table 2 below $^{3}$, we included important variables related to the meaning individuals give to their work, workplace discrimination/harassment, and work-life balance and schedule flexibility (in addition to a range of individual control variables).

\footnotetext{
${ }^{1}$ ISSP Researchers collected the data via self-administered questionnaires, personal interviews, and mail-back questionnaires, depending on the country.

2 For a full summary and description of this research, see https://www.gesis.org/issp/modules/issp-modules-by-topic/work-orientations/2015/.

${ }^{3}$ Each variable is a single-item indicator.
} 


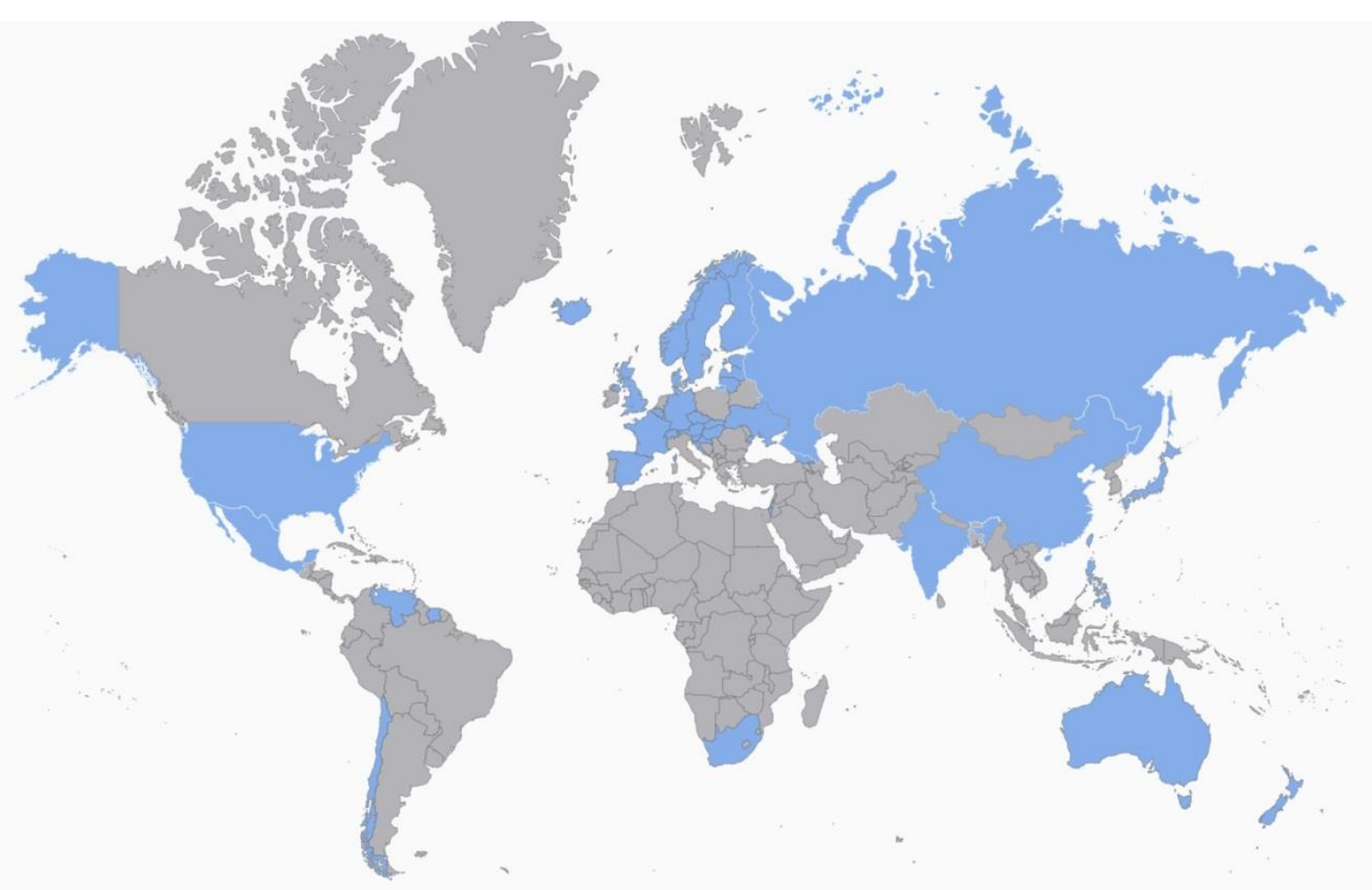

Figure 2. World Map of Study Countries

Table 1. Study countries

1. Australia

2. Austria

3. Belgium

4. Chile

5. China

6. Taiwan

7. Croatia

8. Czech Republic

9. Denmark

10. Estonia

11. Finland

12. France

13. Georgia

14. Germany

15. Hungary

16. Iceland

17. India

18. Israel

19. Japan

20. Latvia

21. Lithuania

22. Mexico 


\section{Macrothink}

International Journal of Human Resource Studies

ISSN 2162-3058 2019, Vol. 9, No. 2

23. New Zealand

\section{Norway \\ 25. Philippines}

26. Poland

27. Russia

28. Slovak Republic

29. Slovenia

30. South Africa

31. Spain

32. Suriname

33. Sweden

34. Switzerland

35. United Kingdom

36. United States

37. Venezuela

Table 2. Key work characteristics related to job satisfaction

\section{Dependent Variable:}

Job Satisfaction ${ }^{4}$

"How satisfied are you in your main job?"

Intrinsic Rewards ${ }^{5}$ :

Interesting Job

"My job is interesting."

Job Autonomy

"I can work independently."

Help Others

"In my job I can help other people."

Job Useful to Society

"My job is useful to society."

\section{Extrinsic Rewards ${ }^{6}$ :}

Pay

Job Security

Promotional Opportunities

Physical Effort ${ }^{7}$

Work Stress $^{8}$
"My income is high."

"My job is secure."

"My opportunities for advancement are high."

"How often do you have to do hard physical work?"

"How often do you find your work stressful?"

Work Relations:

Management-Employee Relations ${ }^{9}$

"In general, how would you describe relations at your workplace between management and employees?"

\footnotetext{
${ }^{4}$ Response categories for this variable include: (1) Completely Dissatisfied, (2) Very Dissatisfied, (3) Fairly Dissatisfied, (4) Neither Satisfied nor Dissatisfied, (5) Fairly Satisfied, (6) Very Satisfied, (7) Completely Satisfied.

5 Response categories for these variables include: (1) Strongly Disagree, (2) Disagree, (3) Neither Agree nor Disagree, (4) Agree, and (5) Strongly Agree.

6 Response categories for these variables include: (1) Strongly Disagree, (2) Disagree, (3) Neither Agree nor Disagree, (4) Agree, and (5) Strongly Agree.

7 Response categories for this variable include: (1) Always, (2) Often, (3) Sometimes, (4) Hardly Ever, (5) Never.

8 Response categories for this variable include: (1) Always, (2) Often, (3) Sometimes, (4) Hardly Ever, (5) Never.

9 Response categories for these variables include: (1) Very Bad, (2) Bad, (3) Neither good nor bad, (4) Good, and (5) Very Good.
} 


\section{Il Macrothink}

Coworker Relations ${ }^{10}$

Contact with Others ${ }^{11}$

Harassed at Work ${ }^{13}$
Discriminated against at Work $^{12}$

International Journal of Human Resource Studies

ISSN 2162-3058

2019, Vol. 9, No. 2

"In general, how would you describe relations at your workplace between workmates/colleagues?"

"In my job, I have personal contact with others."

"Over the past 5 years, have you been discriminated against with regard to work, for instance, when applying for a job, or when being considered for a pay increase or promotion?"

"Over the past 5 years, have you been harassed by your supervisors or coworkers at your job, for example, have you experienced any bullying, physical, or psychological abuse?"

\section{Work-Life Balance}

Work from Home ${ }^{14}$

Work Weekends ${ }^{15}$

Schedule Flexibility ${ }^{16}$

"How often does your job involve working weekends?

"Which of the following best describes how your working hours are decided (times you start and finish your work)?

Flexibility to Deal with Family Matters ${ }^{17}$

"How difficult would it be for you to take an hour or two off during work hours, to take care of personal or family matters?

Work Interferes with Family ${ }^{18}$
"How often do you feel that the demands of your job interfere with your family?"

\subsection{Individual and Family Circumstances and Characteristics}

While there are many possible control variables that would be helpful in this analysis, availability of all such variables is not consistent across all countries in the 2015 ISSP Work Orientations data. As such, control variables used in this analysis were limited to the following individual characteristics: (1) $\mathrm{Sex}^{19}$, (2) $\mathrm{Age}^{20}$, (3) Years of Education ${ }^{21}$, (4) Marital Status $^{22}$, and (5) Size of Family ${ }^{23}$ (see Hammermesh, 1999; Souza-Poza \& Souza-Poza, 2000;

\footnotetext{
${ }^{10}$ Response categories for these variables include: (1) Very Bad, (2) Bad, (3) Neither good nor bad, (4) Good, and (5) Very Good.

11 Response categories for these variables include: (1) Strongly Disagree, (2) Disagree, (3) Neither Agree nor Disagree, (4) Agree, and (5) Strongly Agree.

${ }_{12}$ Response categories for these variables include: (1) Yes, (2) No.

13 Response categories for these variables include: (1) Yes, (2) No.

14 Response categories for this variable include: (1) Always, (2) Often, (3) Sometimes, (4) Hardly Ever, (5) Never.

15 Response categories for this variable include: (1) Always, (2) Often, (3) Sometimes, (4) Hardly Ever, (5) Never.

${ }^{16}$ Response categories for this variable include: (1) Starting and finishing times are decided by my employer and I cannot change them on my own, (2) I can decide the times I start and finish work, within certain limits, and (3) I am entirely free to decide when I start and finish work.

17 Response categories for this variable include: (1) Not difficult at all, (2) Not too difficult, (3) Somewhat difficult, and (4) Very difficult.

18 Response categories for this variable include: (1) Always, (2) Often, (3) Sometimes, (4) Hardly Ever, (5) Never.

19 Categories for this variable include: (1) Male, (2) Female.

${ }^{20}$ Continuous variable.

${ }^{21}$ Continuous variable.

${ }^{22}$ Response categories for this variable include: (1) married, (2) civil partnership, (3) separated from spouse/civil partner(s), (4) divorced from spouse/ legally separated, (5) widowed/ civil partner died, (6) never married/ never in a civil partner
} 
Hodson, 2002; Carlson \& Mellor, 2004).

\subsection{Organizational and Job Characteristics}

While there are many possible control variables that would be helpful in this analysis, availability of all such variables is not consistent across all countries in the 2015 ISSP Work Orientations data. As such, organizational and job characteristics control variables used in this analysis were limited to the following: (1) Work Hours ${ }^{24}$, (2) ISCO Job Classification ${ }^{25}$, (3) Supervisory Status ${ }^{26}$, (4) Employment Relationship ${ }^{27}$, and (5) Public/Private Organization $^{28}$ (see Hammermesh, 1999; Souza-Poza \& Souza-Poza, 2000).

\subsection{A Note on Cross-Cultural Variation}

In any research comparing data from various countries throughout the world, cross-cultural variation and culturally motivated bias in responses is always a potential concern. Though this research is not designed to be cross-cultural, per se, it is important to understand the possible implications of culturally-motivated biased perceptions in responses, due to the cross-national comparative nature of this research. Fischer (2004) explained, "Response bias is the systematic tendency to distort responses to rating scales so that observed scores are unrelated to the true score of the individual by either selecting extreme or modest answers (extreme or modesty response bias) or a shifting of responses to either end of the scale (acquiescence response bias)" (p. 263; see also Byrne \& Campbell, 1999; Cheung \& Rensvold, 2000). Additionally, Sousa-Pouza \& Sousa-Pouza (2000) state, "If the questionnaire or the topic being studied is 'ethnically biased,' then errors in perception will occur” (p. 521). Indeed, a cross-national analysis of subjective variables can produce a number of data and methodological problems ${ }^{29}$. However, several researchers have found that individuals compare their situation to those around them, and that happiness and well-being is based on this relative comparison (Clark \& Oswald, 1996; Diener et al., 1995).

${ }^{23}$ Continuous variable.

${ }^{24}$ Continuous variable.

${ }^{25}$ Categories for this variable include: (1) Managers, (2) Professionals, (3) Technicians and Associate Professionals, (4)

Clerical Support Workers, (5) Services and Sales Workers, (6) Skilled Agricultural, Forestry and Fishery Workers, (7) Craft and Related Trades Workers, (8) Plant and Machine Operators and Assemblers, (9) Elementary Occupations, and (10) Armed Forces Occupations

${ }^{26}$ Categories for supervising others: (1) Yes, (2) No.

${ }^{27}$ Categories for this variable include: (1) Employee, (2) self-employed without employees, (3) self-employed with employees, and (4) working for own family's business.

${ }_{28}$ Categories for type of organization: (1) Public, (2) Private

${ }^{29}$ Despite these data and methodological problems, the use of data standardization, as an adjustment of raw scores in cross-cultural research to correct for such response tendencies, is used to reduce or eliminate unwanted cross-cultural differences that are not due to variables of interest, but rather response sets and methodological artifacts (see Hofstede, 1980). Detecting potential response bias requires researchers to identify different response patterns based on particular methods used and eliminate them. Furthermore, researchers need to detect and control for this bias or error variance in cross-cultural research, and assuming that different patterns are some form of bias, researchers need to standardize their data to reduce this error variance (Fischer, 2004). In the ISSP data, the original researchers have already taken appropriate methodological precautions against response bias, and additionally I have adjusted the raw scores through data standardization and reporting beta coefficients, thus "remov[ing] variation that is substantial and related to culture" (Fischer, 2004, p. 264). 
Furthermore, most studies examining job satisfaction are based on this type of data (Sousa-Pouza \& Sousa-Pouza, 2000).

\section{Statistical Methodology}

We analyzed work orientation and job satisfaction data from individual respondents in the 37 countries included in the 2015 Work Orientations wave of the International Social Survey Program. First we performed a range of bivariate and multivariate analyses (e.g. correlations, cross-tabulations, trend analysis, ANOVA and ANCOVA procedures, and general descriptive statistics) on the work characteristics and attitudes in each country, which provides a basis for making descriptive comparisons between countries. Additionally, we ran aggregate and country-specific OLS regression models to examine the differences between countries in the impact of individual work characteristics on job satisfaction. It is worth noting that some studies examining worker satisfaction have used Ordinary Least Squares Regression (OLS) (see Handel, 2005), others have pointed to ordered probit regression (used when the dependent variable is ordered and categorical). I ran identical models using both OLS and ordered probit procedures (see Souza-Poza and Souza-Poza, 2000) ${ }^{30}$. Upon comparing the OLS and ordered probit results, I have come to the same conclusion that for the purposes of comparing coefficients and significance across countries and across models, as well as for overall ease of interpretation of the results, OLS is sufficient (however, full ordered probit results are all available upon request).

\subsection{Limitations of the Data}

One of the primary limitations of the available attitudinal data is that each question represents a subjective single item indicator. As Souza-Poza and Souza-Poza (2000) aptly point out, "[Subjective Well Being] scores depend on the type of scale used, the ordering of the items, the time-frame of the questions, the current mood at the time of measurement, and other situational factors" (p. 5; see also Diener, Diener, \& Diener, 1999). They further point out that, as the ISSP data set only measures job satisfaction as a single-item indicator, variance due to the wording of the item cannot be averaged out and the single item further makes the evaluation of internal consistency problematic. Another problem is the non-panel longitudinal nature of the data. Here we use one of four waves of cross-sectional data and therefore we cannot specifically test the direction of causality among the variables examined as easily as we might with panel longitudinal data. However, we provide a conceptual framework that hypothesizes the path of causality. Additionally, some variables of interest and other important control variables cannot be included in the analysis, as data are not available for each wave of data collection across all countries of interest.

\footnotetext{
${ }^{30}$ Due to the ordinal nature of the dependent variable, it is most appropriate to use an ordered probit regression to look at the effect of different job characteristics on one's overall job satisfaction. However, many researchers have argued that using OLS regression is appropriate when looking at satisfaction variables on a Likert scale, where most respondents understand that the difference between responses of 1 and 2 is the same as the difference between responses of 2 and 3 , and so on. Additionally, using OLS regression results allows us to report an r-squared and adjusted r-squared value for the model and compare coefficients across models, which comparison is not appropriate in a probit model. Therefore, all regression results reported herein are OLS regression result. It is important to note that when the same OLS models where run in an ordered probit regression, the same significant results appeared for each of the independent and control variables across countries and waves (full ordered probit model results, are available upon request).
} 


\section{Results}

\subsection{Mean Job Satisfaction by Country and Workforce Demographics}

Figure 3 below shows mean job satisfaction levels across the 37 countries included in the 2015 wave of ISSP Work Orientations data. Of note is the general variation across countries and regions of the world. The highest job satisfaction levels are in Venezuela, Switzerland, Austria, and Mexico (means between 5.7-5.9), while most countries have a mean job satisfaction scores in the 5.2-5.4 range (overall world-wide mean is 5.3). Poland, China, and Japan have the lowest mean job satisfaction scores (means between 4.5-4.8).

Additionally, Table 3 shows the means of some core demographic characteristics, by country, including age, years of education, size of family, and hours worked per week. There is wide variation in the average age of the workforce of each country sample (average for all countries is over 43 years old), with New Zealand and Australia having the oldest average workforce (over 49 years old) and Mexico having the youngest average workforce (just over 36 years old). Additionally, Iceland and France have the highest average years of education (over 15 years each), while the Philippines has the lowest (just over 9 years of formal education) and the average for all countries is a little over 13 years of formal education. India has the largest average family size (of those living at home) of 5.6, while Austria has the smallest average family size of 2.32 (and an average across all countries of 3.23). Finally, Australia has the lowest average hours worked per week (just under 37) and China has the highest (49.43), and an average across all countries of nearly 41 hours worked per week.

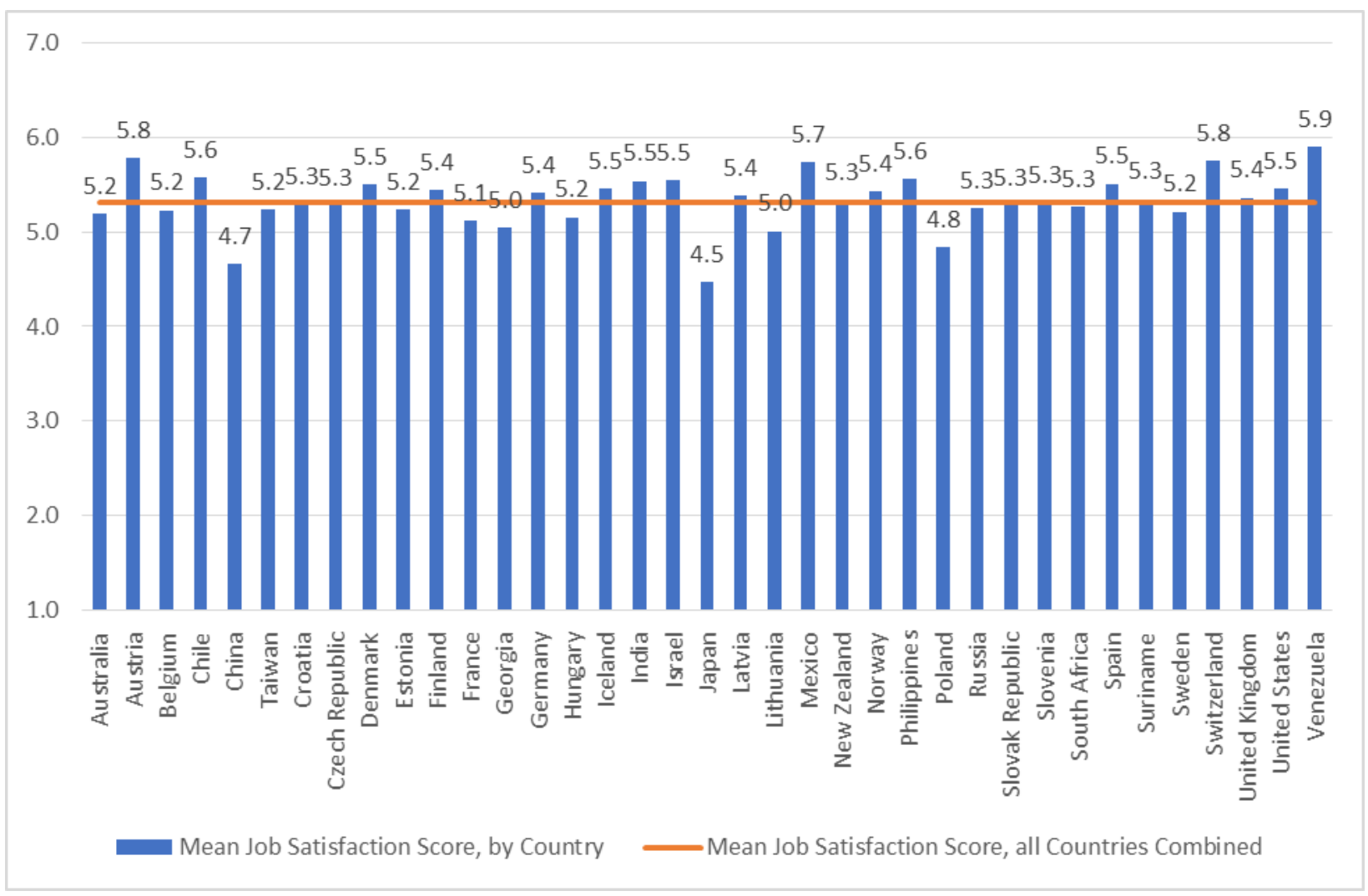

Figure 3. Mean Job Satisfaction by Country, 2015 


\subsection{Regression Models}

In order to build the comprehensive model for job satisfaction, six step-wise regression analyses were conducted on the full aggregated data for all countries in the 2015 ISSP Work Orientations module (see Table 4 below). First, the base model simply regresses job satisfaction on individual control variables. Next, models one through four regress jo satisfaction on the various categories of variables (e.g. intrinsic, extrinsic, work relations, work-life balance). Finally, the combined module includes all variables and their influence on job satisfaction.

Table 3. Mean demographic characteristics, by country

\begin{tabular}{|c|c|c|c|c|}
\hline Country & Age & Years of Education & Size of Family & Work Hours per Week \\
\hline Australia & 49.42 & 14.70 & 2.97 & 36.86 \\
\hline Austria & 40.77 & 11.72 & 2.32 & 39.58 \\
\hline Belgium & 42.45 & 14.37 & 2.91 & 38.56 \\
\hline Chile & 44.86 & 11.88 & 3.53 & 42.89 \\
\hline China & 41.79 & 10.10 & 3.02 & 49.43 \\
\hline Taiwan & 41.83 & 12.97 & 4.42 & 45.86 \\
\hline Croatia & 40.22 & 12.89 & 3.22 & 42.16 \\
\hline Czech Republic & 43.50 & 13.67 & 2.60 & 45.81 \\
\hline Denmark & -- & 15.19 & 2.71 & 37.06 \\
\hline Estonia & 44.63 & 13.67 & 2.55 & 39.95 \\
\hline Finland & 44.99 & 14.87 & 2.71 & 38.04 \\
\hline France & 44.81 & 15.15 & 2.90 & 37.81 \\
\hline Georgia & 46.21 & 14.09 & 3.03 & 38.45 \\
\hline Germany & 43.39 & 13.40 & 2.73 & 37.78 \\
\hline Hungary & 43.42 & 12.71 & 2.41 & 42.55 \\
\hline Iceland & 44.89 & 15.85 & 3.07 & 41.95 \\
\hline India & 40.65 & 10.75 & 5.60 & 46.39 \\
\hline Israel & 43.92 & 14.04 & 3.75 & 39.72 \\
\hline Japan & 47.89 & 13.47 & 3.29 & 39.36 \\
\hline Latvia & 42.67 & 13.71 & 2.80 & 40.93 \\
\hline Lithuania & 41.21 & 14.49 & 2.85 & 42.62 \\
\hline Mexico & 36.18 & 10.67 & 4.31 & 43.26 \\
\hline New Zealand & 49.89 & 14.66 & 2.79 & 37.10 \\
\hline Norway & 45.09 & 14.16 & 2.83 & 37.19 \\
\hline Philippines & 43.13 & 9.11 & 4.63 & 44.20 \\
\hline Poland & 42.68 & 13.27 & 4.18 & 41.75 \\
\hline Russia & 40.22 & 13.27 & 2.97 & 41.52 \\
\hline Slovak Republic & 43.48 & 13.93 & 3.02 & 41.30 \\
\hline Slovenia & 42.52 & 13.85 & 3.41 & 43.11 \\
\hline South Africa & 39.90 & 11.69 & 3.45 & 44.97 \\
\hline Spain & 43.01 & 13.71 & 3.20 & 40.23 \\
\hline Suriname & 42.48 & 10.68 & 3.79 & 40.75 \\
\hline Sweden & 47.29 & 14.07 & 2.80 & 38.64 \\
\hline Switzerland & 43.22 & 13.73 & 2.91 & 38.24 \\
\hline United Kingdom & 44.06 & 15.21 & 2.61 & 37.94 \\
\hline United States & 43.58 & 14.16 & 2.53 & 41.43 \\
\hline Venezuela & 38.79 & 11.13 & 4.97 & 41.49 \\
\hline All Countries & 43.37 & 13.34 & 3.23 & 40.96 \\
\hline
\end{tabular}

When each OLS model was run separately, nearly all variables were statistically significant $(\mathrm{p}<.001)$ (except size of family and working weekends). When all models were included in 
the combined model, statistical significance of some of the variables changed (e.g. working weekends became significant, while physical effort, contact with others, working from home, and several individual control variables fell out of significant in the combined model). The base model (with individual control) predicted 3\% of the variation in job satisfaction (adjusted r-square $=0.031$ ), the intrinsic rewards model predicted $25 \%$ of the variation in job satisfaction (adjusted r-square $=0.253$ ), the extrinsic rewards model predicted nearly $20 \%$ of the variation in job satisfaction (adjusted r-square $=0.197$ ), the work relations model predicted nearly $23 \%$ of the variation in job satisfaction (adjusted r-square $=0.225$ ), and the work-life balance model predicted nearly $8 \%$ of the variation in job satisfaction (adjusted r-square $=0.077$ ). When each smaller model was combined into the holistic job satisfaction model (with all intrinsic, extrinsic, work relations, work-life balance, and control variables), we are able to predict nearly $43 \%$ of the variation in job satisfaction (adjusted r-squared = $0.428)$.

After determining the combined model, we ran a separate OLS regression analysis for all 37 countries included in the 2015 ISSP Work Orientations module. We provide a breakdown of OLS model specifications by country in Tables 7 in Appendix 1 (reporting the comparative predictability (adjusted $r$-squared) of each country model and the standardized beta coefficient and significance for each of the key independent variables in the model. Figure $4^{31}$ demonstrates there is a great deal of variation between countries in standardized beta coefficient strength and statistical significance across study variables. Of particular note is that the model only explains $15 \%$ of the variation in job satisfaction in the Philippines (adjusted r-squared $=0.15$ ), the worst model fit of all 37 countries. Other countries where the model has much lower relative predictability include Suriname (adjusted r-squared $=0.24$ ), China (adjusted r-squared $=0.27$ ), India (adjusted $r$-squared $=0.30$ ), Taiwan (adjusted r-squared $=0.31$ ), Lithuania (adjusted $r$-squared $=0.33$ ), and Georgia (adjusted r-squared = 0.36). In contrast, for all countries the model explains $43 \%$ of the variation in job satisfaction (adjusted r-squared $=0.43$ ), and many countries are much higher, with the clear winner being Australia, where the model explains $63 \%$ of the variation in job satisfaction. Other countries where the model has a much higher relative predictability include Sweden (adjusted r-squared $=0.58$ ), Finland (adjusted r-squared $=0.57$ ), Denmark (adjusted r-squared $=0.56$ ), Iceland (adjusted r-squared $=0.56$ ), Japan (adjusted r-squared $=0.56$ ), and the UK (adjusted r-squared $=0.55$. The model predicts $47 \%$ of the variation in job satisfaction in the United States (adjusted r-squared $=0.47$ ).

${ }^{31}$ Full country-specific OLS regression results available in Appendix 1. 
Table 4. OLS regression of job satisfaction and main study variables, 2015

\begin{tabular}{|c|c|c|c|c|c|c|}
\hline Variable & $\begin{array}{l}\text { Base Model: } \\
\text { Controls }\end{array}$ & $\begin{array}{c}\text { Model 1: } \\
\text { Intrinsic Rewards }\end{array}$ & $\begin{array}{c}\text { Model 2: } \\
\text { Extrinsic Rewards }\end{array}$ & $\begin{array}{c}\text { Model 3: } \\
\text { Work Relations }\end{array}$ & $\begin{array}{c}\text { Model 4: } \\
\text { Work-Life } \\
\text { Balance }\end{array}$ & $\begin{array}{c}\text { Combined } \\
\text { Model }\end{array}$ \\
\hline Gender & $-0.037(0.016)^{* * *}$ & & & & & $0.005(.014)$ \\
\hline Age & $0.029(.001)^{* * * *}$ & & & & & $0.033(.001)^{* * * *}$ \\
\hline Education & $-0.052(.002)^{* * *}$ & & & & & $-0.045(.002)^{* * *}$ \\
\hline Marital Status & $-0.025(.004)^{* * *}$ & & & & & $-0.028(.003)^{* * *}$ \\
\hline Size of Family & $-0.008(.005)$ & & & & & $-0.007(.004)$ \\
\hline Work Hours & $-0.022(.001)^{* * *}$ & & & & & $0.006(.001)$ \\
\hline Job Classification & $-0.125(.004)^{* * *}$ & & & & & $-0.009(.003)$ \\
\hline Supervisory Status & $-0.051(.018)^{* * *}$ & & & & & $-0.004(.016)$ \\
\hline Employment Relationship & $0.075(.013)^{* * *}$ & & & & & $0.008(.013)$ \\
\hline Public/Private Organization & $-0.052(* * *)$ & & & & & $-0.028(.015)^{* * *}$ \\
\hline Interesting Work & & $0.419(.007)^{* * * *}$ & & & & $0.287(.008)^{* * *}$ \\
\hline Job Autonomy & & $0.098(.006)^{* * * *}$ & & & & $0.019(.007)^{* *}$ \\
\hline Help Others & & $0.031(.008)^{* * * *}$ & & & & $0.022(.009)^{* *}$ \\
\hline Job Useful to Society & & $0.047(.008)^{* * *}$ & & & & $0.037(.009)^{* * *}$ \\
\hline Job Security & & & $0.162(.006)^{* * *}$ & & & $0.063(.007)^{* * *}$ \\
\hline Pay & & & $0.162(.007)^{* * * *}$ & & & $0.098(.007)^{* * * *}$ \\
\hline Promotional Opportunities & & & $0.179(.007)^{* * *}$ & & & $0.057(.007)^{* * *}$ \\
\hline Physical Effort & & & $-0.047(.005)^{* * *}$ & & & $0.005(.006)$ \\
\hline Work Stress & & & $-0.179(.006)^{* * *}$ & & & $-0.086(.007)^{* * *}$ \\
\hline Relations with Coworkers & & & & $0.144(.010)^{* * * *}$ & & $0.085(.010)^{* * *}$ \\
\hline Relations with Management & & & & $0.348(.009)^{* * * *}$ & & $0.225(.009)^{* * * *}$ \\
\hline Contact with Others & & & & $0.122(.008)^{* * *}$ & & $0.010(.009)$ \\
\hline Discriminated Against at Work & & & & $0.072(.017)^{* * *}$ & & $0.037(.018)^{* * *}$ \\
\hline Harassed at Work & & & & $0.044(.019)^{* * *}$ & & $0.019(.020)^{* * * *}$ \\
\hline Work from Home & & & & & $-0.073(.006)^{* * *}$ & $0.005(.006)$ \\
\hline Work Weekends & & & & & $0.008(.005)$ & $-0.023(.005)^{* * *}$ \\
\hline Schedule Flexibility & & & & & $0.068(.011)^{* * * *}$ & $0.014(.012)^{*}$ \\
\hline Flexibility to Deal with Family Matters & & & & & $-0.134(.007)^{* * *}$ & $-0.036(.007)^{* * *}$ \\
\hline Work Interferes with Family & & & & & $0.173(.007)^{* * *}$ & $0.097(.007)^{* * *}$ \\
\hline$N$ & 22,418 & 21,102 & 26,628 & 24,634 & 25,966 & 18,716 \\
\hline Adjusted R-square & 0.031 & 0.253 & 0.197 & 0.225 & 0.077 & 0.428 \\
\hline $\begin{array}{l}\text { Change in Adjusted R-square } \\
\text { (from base model) }\end{array}$ & - & 0.222 & 0.166 & 0.194 & 0.047 & 0.397 \\
\hline$F$ & $72.40^{* * * *}$ & $2293.11^{* * *}$ & $1308.38^{* * *}$ & $1686.99 * * *$ & $436.80^{* * *}$ & $483.58^{* * *}$ \\
\hline
\end{tabular}

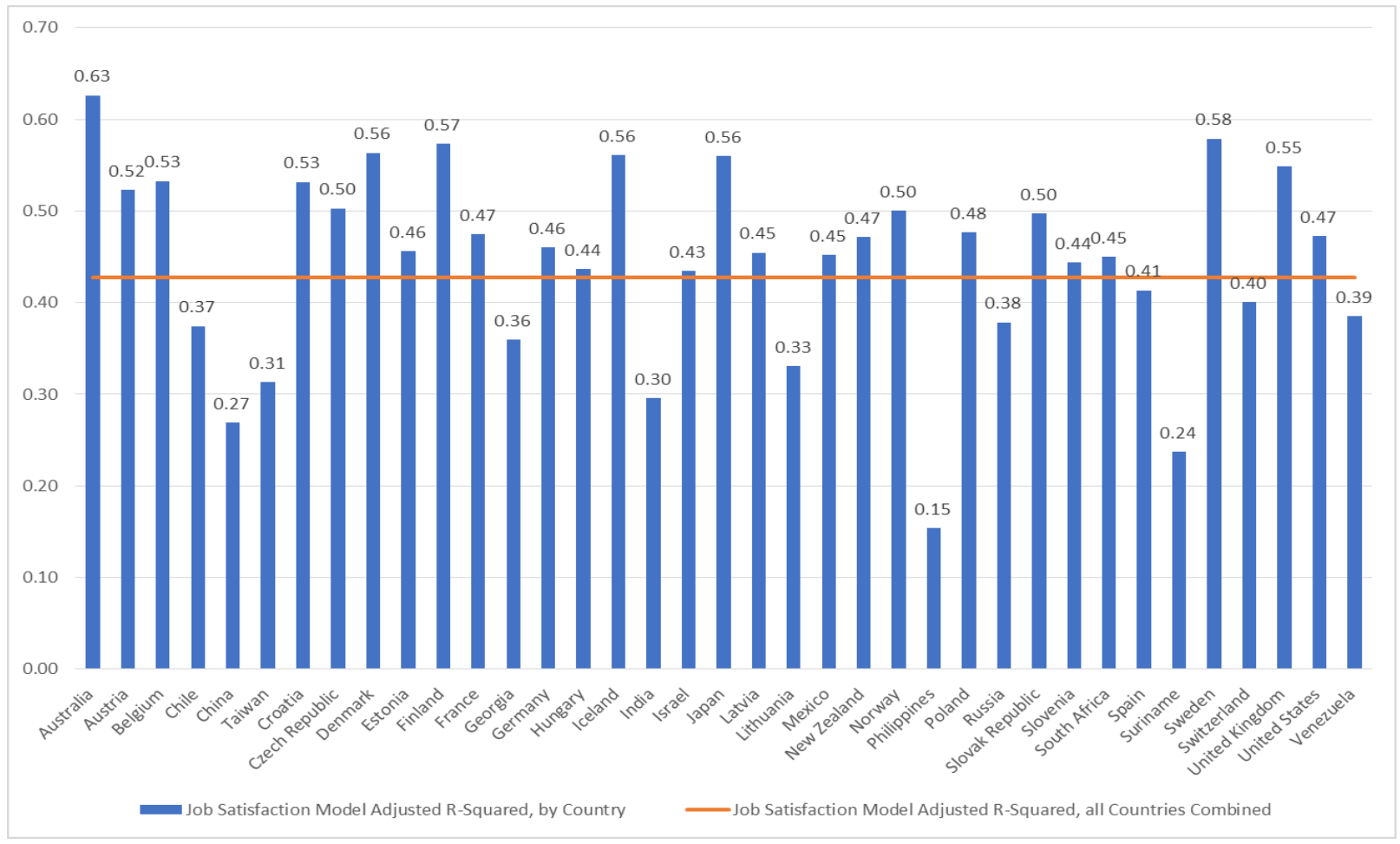

Figure 4. Model Fit: Job Satisfaction Model Adjusted R-Squared, by Country

Additionally, we see several patterns emerge when we compare country-specific variations in 
the OLS regression results (see Appendix 1). First of all, certain variables are significant in nearly every country, including interesting work, pay, work stress, relationships with coworkers and management, and work interferes with family, while the significance of most other variables (including control variables) vary widely across different countries and regions of the world. These regression findings clearly support H1a and H1b, that there are statistically significant cross-national differences in the levels of job satisfaction across countries and statistically significant cross-national differences in the determinants of job satisfaction across countries.

\subsubsection{Work-Life Balance and Schedule Flexibility Variables}

One of the specific contribution of this study is looking at the impact of work-life balance and schedule flexibility variables on job satisfaction. Countless previous studies have looked at the impact of various intrinsic, extrinsic, and workplace relations variables. However, very few have examined the role of work-life balance, and none have examined these variables cross-nationally. In what follows, we specifically focus on the work-life balance and schedule flexibility variables, first looking at the descriptive mean scores and cross-tabulation results, followed by regression results.

Table 5 shows work-life balance and schedule flexibility variables mean scores, by country. First, we see that most workers across the 37 countries included in the 2015 wave of the Work Orientations data hardly ever work from home. The two main exceptions are the Philippines and India, which both have a more workers that always, often, or sometimes work from how than those that don't. Of the 37 countries, workers in the Czech Republic, Austria, Latvia, and Japan are the least likely to work from home. Second, we see that most workers across the 37 countries have to work weekends sometimes, with workers in China, the Philippines, Mexico, Japan, and India being those most likely to work weekends and workers in Austria, Israel, Sweden, and Switzerland being the least likely. Third, we see that most workers across the 37 countries work a regular schedule or shift, with some variation, while workers in Russia, Croatia, Hungary, and South Africa have the most standardized schedules and workers in the Philippines are most likely to have a more volatile schedule that is determined by the manager on short notice. Fourth, we see that most workers across the 37 countries would not have a difficult time taking a couple hours off during work hours to deal with family or personal matters, while workers in New Zealand, Switzerland, Sweden, Denmark, Finland, Iceland, and the United States have the most flexibility to deal with family matters and workers in Russia, Japan, the Slovak Republic, France, and Venezuela have the least amount of flexibility to deal with family matters during work hours. Finally, we see that for most workers across the 37 countries, it is not the perception that work often interferes with family life, while it is most likely to interfere with workers in India, and least likely to interfere with workers in Georgia, Suriname, Taiwan, Hungary, Estonia, and Austria. 
Table 5. Work-life balance and schedule flexibility variables mean Scores, by country

\begin{tabular}{|c|c|c|c|c|c|c|}
\hline \multirow[b]{2}{*}{ Country } & \multicolumn{6}{|c|}{ Mean Scores } \\
\hline & $\begin{array}{c}\text { Job } \\
\text { Satisfaction }\end{array}$ & $\begin{array}{l}\text { Work } \\
\text { from } \\
\text { Home }\end{array}$ & $\begin{array}{c}\text { Work } \\
\text { Weekends }\end{array}$ & $\begin{array}{l}\text { Schedule } \\
\text { Flexibility }\end{array}$ & $\begin{array}{c}\text { Flexibility to Deal } \\
\text { with Family } \\
\text { Matters }\end{array}$ & $\begin{array}{c}\text { Work } \\
\text { Interferes } \\
\text { with Family } \\
\end{array}$ \\
\hline Australia & 5.20 & 3.96 & 3.15 & 1.66 & 2.00 & 3.24 \\
\hline Austria & 5.79 & 4.35 & 3.55 & 1.56 & 2.43 & 4.02 \\
\hline Belgium & 5.23 & 3.96 & 3.23 & 1.63 & 2.48 & 3.36 \\
\hline Chile & 5.58 & 3.84 & 3.21 & 1.60 & 2.26 & 3.74 \\
\hline China & 4.66 & 3.66 & 2.43 & 1.64 & 2.01 & 3.79 \\
\hline Taiwan & 5.24 & 4.16 & 2.88 & 1.73 & 2.22 & 4.14 \\
\hline Croatia & 5.30 & 4.27 & 3.01 & 1.37 & 2.43 & 3.66 \\
\hline Czech Republic & 5.28 & 4.36 & 3.28 & 1.60 & 2.42 & 3.60 \\
\hline Denmark & 5.51 & -- & -- & 1.84 & 1.94 & 3.48 \\
\hline Estonia & 5.24 & 4.17 & 3.37 & 1.56 & 2.34 & 4.07 \\
\hline Finland & 5.45 & 4.03 & 3.38 & 1.82 & 1.94 & 3.52 \\
\hline France & 5.12 & 4.05 & 3.32 & 1.57 & 2.56 & 3.37 \\
\hline Georgia & 5.05 & 3.89 & 3.04 & 1.49 & 2.26 & 4.47 \\
\hline Germany & 5.41 & 4.28 & 3.45 & 1.73 & 2.30 & 3.45 \\
\hline Hungary & 5.16 & 4.23 & 3.44 & 1.38 & 2.35 & 4.08 \\
\hline Iceland & 5.46 & 4.05 & 3.09 & 1.57 & 1.93 & 3.62 \\
\hline India & 5.54 & 2.91 & 2.90 & 1.72 & 2.36 & 2.92 \\
\hline Israel & 5.54 & 3.73 & 3.50 & 1.78 & 2.34 & 3.75 \\
\hline Japan & 4.47 & 4.33 & 2.64 & 1.51 & 2.65 & 3.68 \\
\hline Latvia & 5.39 & 4.35 & 3.28 & 1.52 & 2.02 & 3.96 \\
\hline Lithuania & 5.01 & 4.25 & 3.31 & 1.49 & 2.08 & 3.85 \\
\hline Mexico & 5.75 & 4.06 & 2.64 & 1.63 & 2.40 & 3.54 \\
\hline New Zealand & 5.34 & 4.03 & 3.03 & 1.74 & 1.85 & 3.36 \\
\hline Norway & 5.43 & 3.93 & 3.23 & 1.67 & 2.11 & 3.62 \\
\hline Philippines & 5.56 & 2.41 & 2.56 & 2.17 & 2.37 & 3.55 \\
\hline Poland & 4.84 & 4.19 & 3.07 & 1.57 & 2.45 & 3.72 \\
\hline Russia & 5.25 & 4.17 & 3.41 & 1.30 & 2.82 & 3.92 \\
\hline Slovak Republic & 5.28 & 4.29 & 3.19 & 1.60 & 2.52 & 3.96 \\
\hline Slovenia & 5.31 & 3.79 & 3.19 & 1.60 & 2.09 & 3.64 \\
\hline South Africa & 5.27 & 3.85 & 3.12 & 1.39 & 2.33 & 3.63 \\
\hline Spain & 5.51 & 4.29 & 3.04 & 1.52 & 2.11 & 3.46 \\
\hline Suriname & 5.35 & 3.53 & 3.04 & 1.59 & 2.03 & 4.22 \\
\hline Sweden & 5.22 & 4.07 & 3.46 & 1.82 & 1.95 & 3.36 \\
\hline Switzerland & 5.76 & 4.10 & 3.41 & 1.82 & 1.91 & 3.62 \\
\hline United Kingdom & 5.36 & 4.07 & 3.09 & 1.58 & 2.15 & 3.28 \\
\hline United States & 5.46 & 3.98 & 2.93 & 1.63 & 1.95 & 3.48 \\
\hline Venezuela & 5.91 & 3.77 & 3.24 & 1.66 & 2.56 & 3.86 \\
\hline All Countries & 5.32 & 4.00 & 3.14 & 1.63 & 2.25 & 3.66 \\
\hline
\end{tabular}




\subsubsection{Working from Home}

Figure 5 shows a clear linear relationship between flexibility to work from home and worker job satisfaction - with mean scores declining from above 5.5 for those who always work from home to just over 5.2 for those who never work from home.

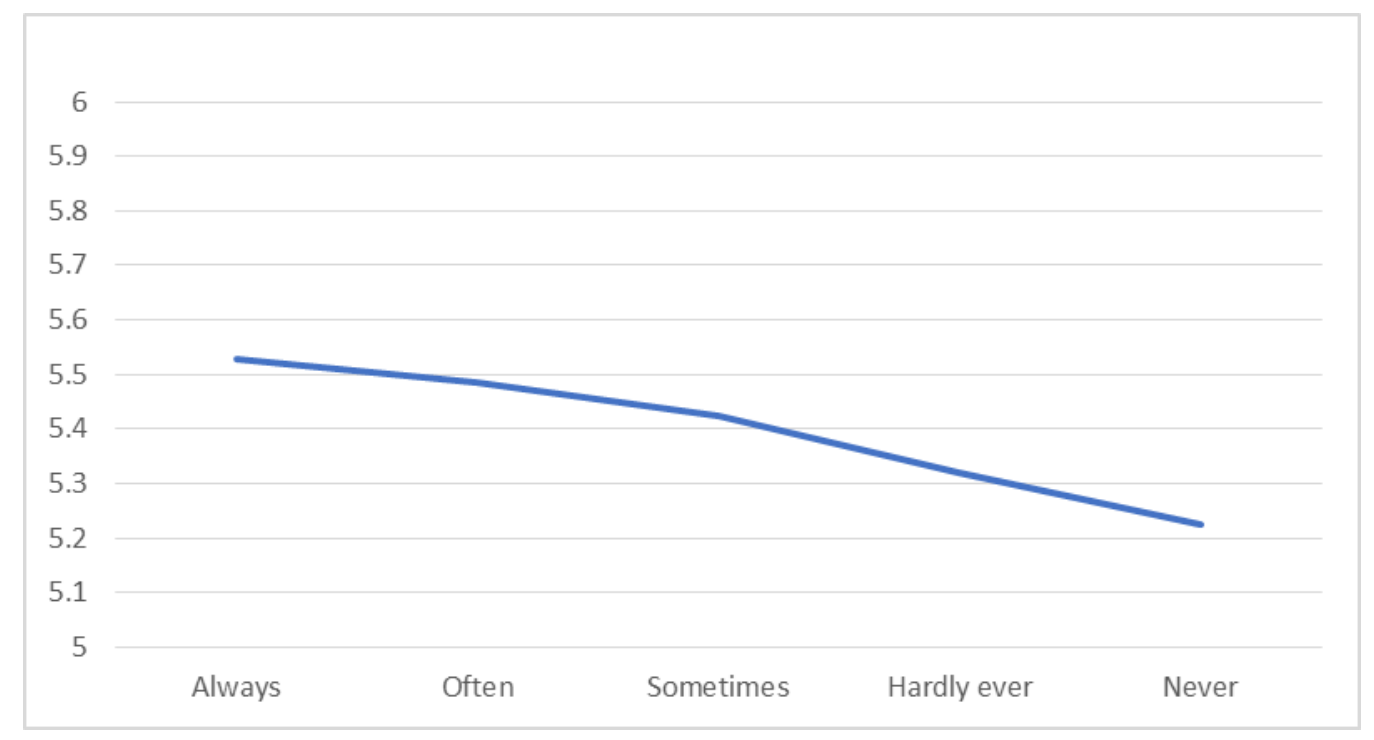

Figure 5. Job Satisfaction Mean Scores: How Often Do You Work From Home During Usual Working Hours?

\subsubsection{Working Weekends}

Figure 6 shows a clear linear relationship between working weekends and worker job satisfaction-with mean scores increasing from just above 5.2 for those who always work weekends to nearly 5.4 for those who never work weekends.

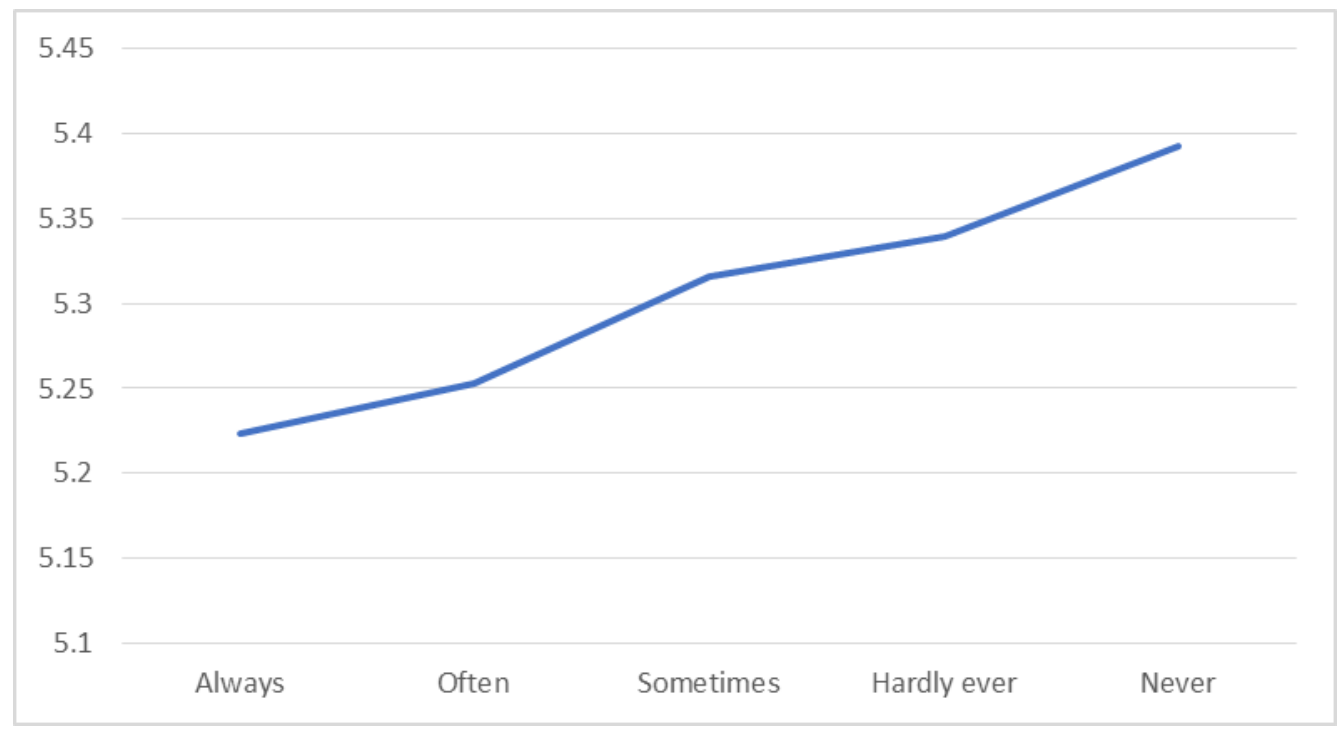

Figure 6. Job Satisfaction Mean Scores: How Often Does Your Job Involve Working on Weekends? 


\section{Macrothink}

International Journal of Human Resource Studies

ISSN 2162-3058 2019, Vol. 9, No. 2

\subsubsection{Schedule Flexibility}

Figures 7 and 8 show mean scores and variable tabulations for working schedule. Figure 7 shows a clear linear relationship between consistent and structured work schedules and worker job satisfaction - with mean scores decreasing from above 5.3 for those who have a regular schedule or shift to just above 5.2 for those who have a schedule where daily working times are decided at short notice by the employer. Moreover, Figure 8 shows a clear linear relationship between how work schedules are decided and worker job satisfaction - with mean scores increasing from just under 5.2 for those who have no flexibility in shifting their assigned work schedule to above 5.6 for those who are able to decide when they start and finish their work.

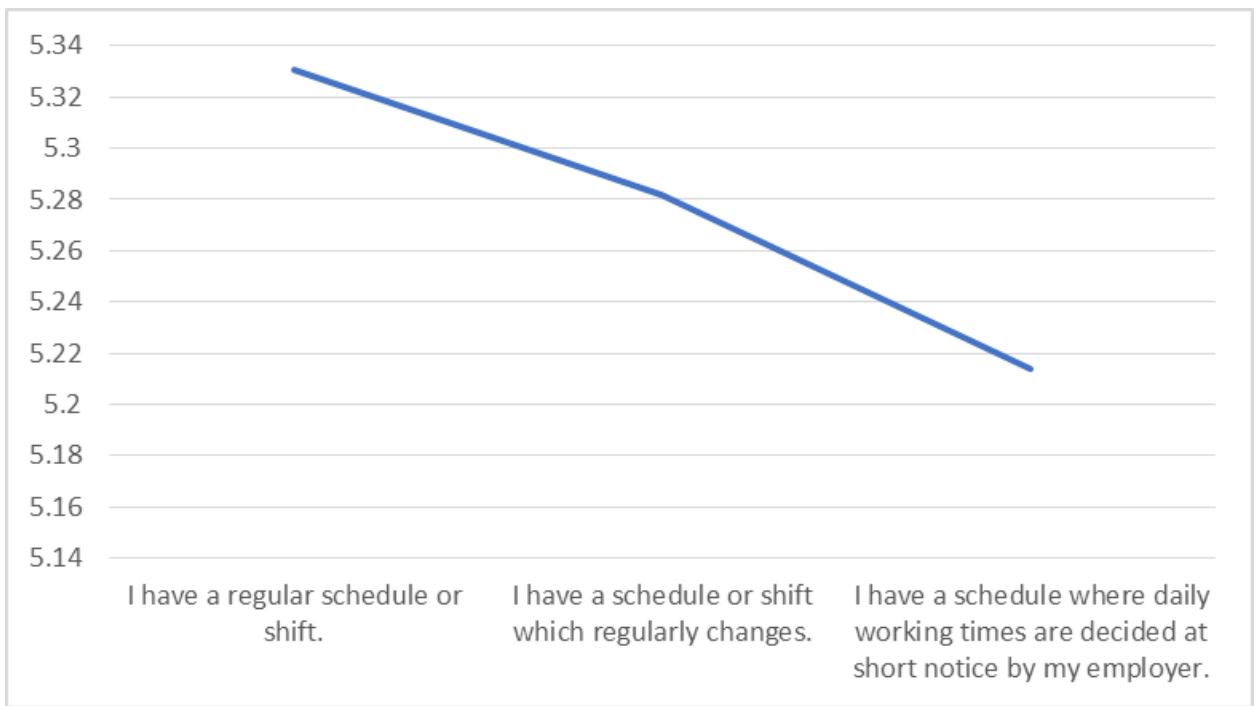

Figure 7. Job Satisfaction Mean Scores: Which Of The Following Statements Best

Describes Your Usual Working Schedule In Your Main Job?

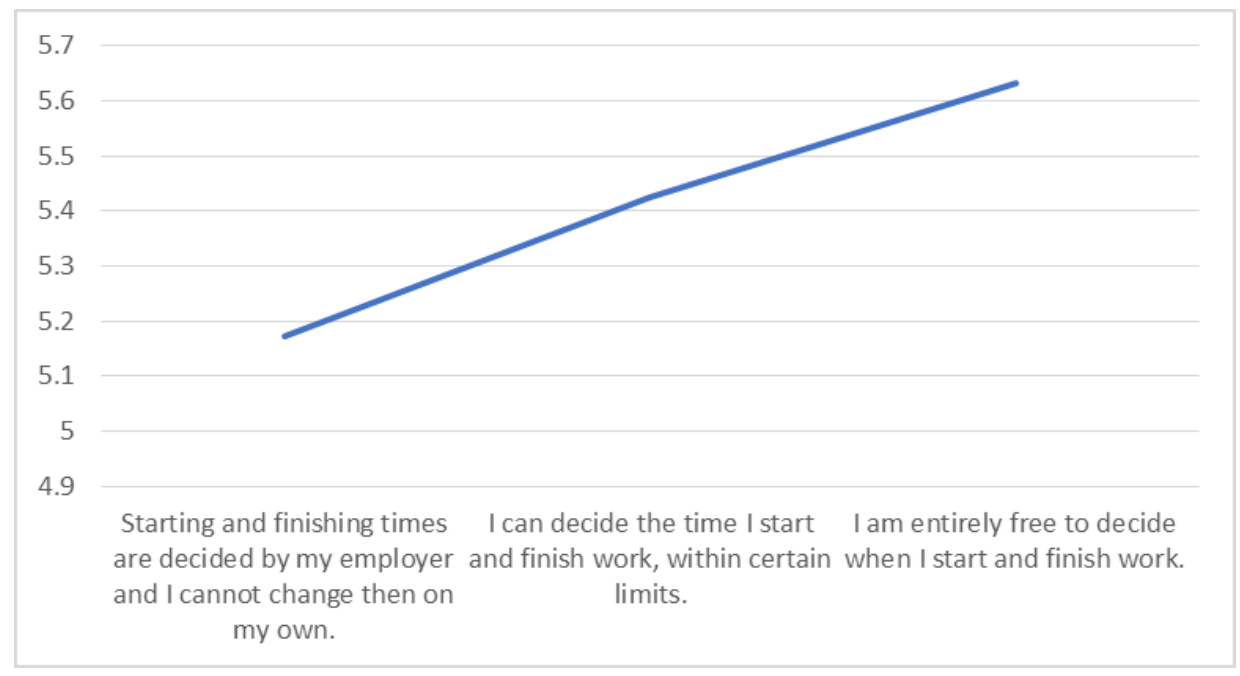

Figure 8. Job Satisfaction Mean Scores: Which Of The Following Statements Best Describes How Your Working Hours Are Decided? 


\section{Macrothink}

\subsubsection{Flexibility to Deal with Family Matters}

Figure 9 shows a clear linear relationship between flexibility of a worker to deal with family matters and worker job satisfaction-with mean scores decreasing from nearly 5.7 for those who have no difficulty taking an hour or two off during working hours to deal with personal matters to under 5 for those who find it very difficult.

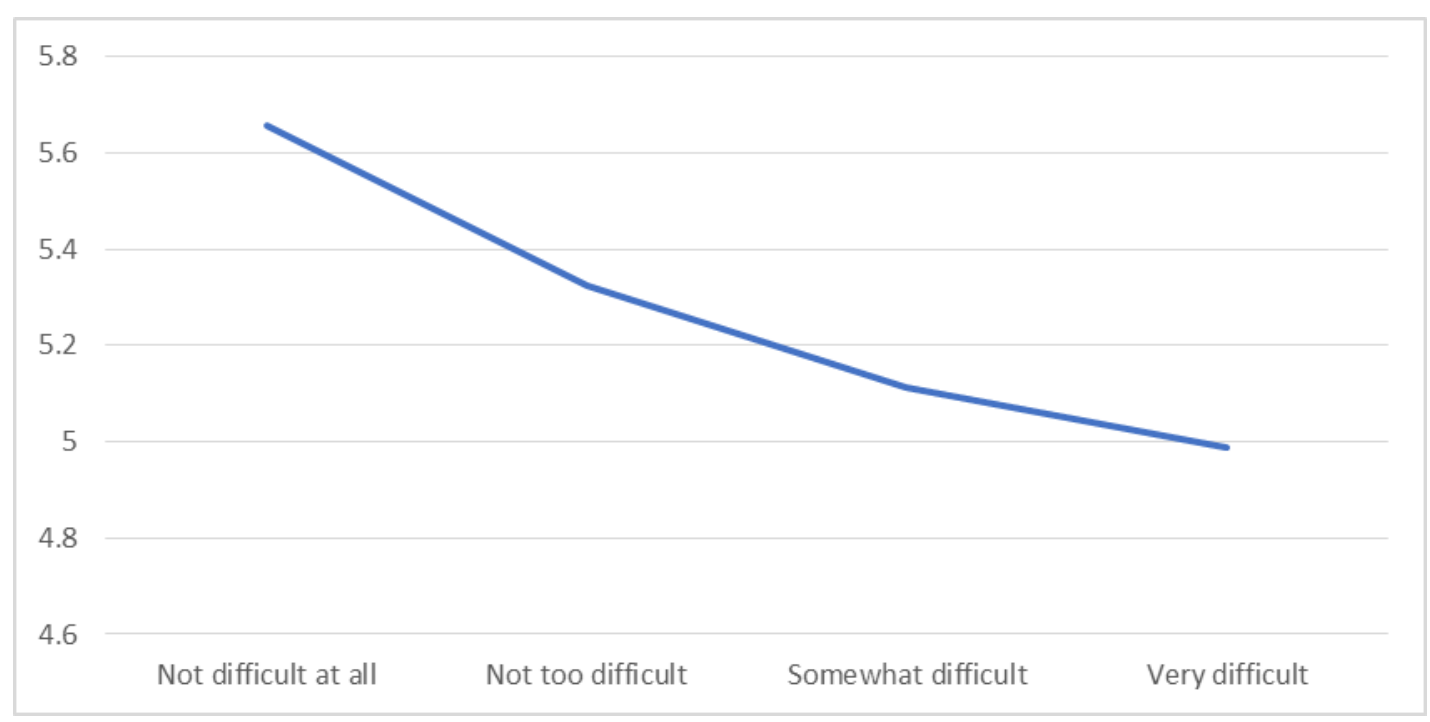

Figure 9. Job Satisfaction Mean Scores: How Difficult Would It Be For You To Take An Hour Or Two Off During Working Hours, to Take Care of Personal or Family Matters?

\subsubsection{Job Interferes with Family}

Figure 10 shows a clear linear relationship between how often work interferes with family and worker job satisfaction-with mean scores increasing from under 4.8 for those who always feel that the demands of their job interfere with their family life to 5.6 for those who never have work interfere with family.

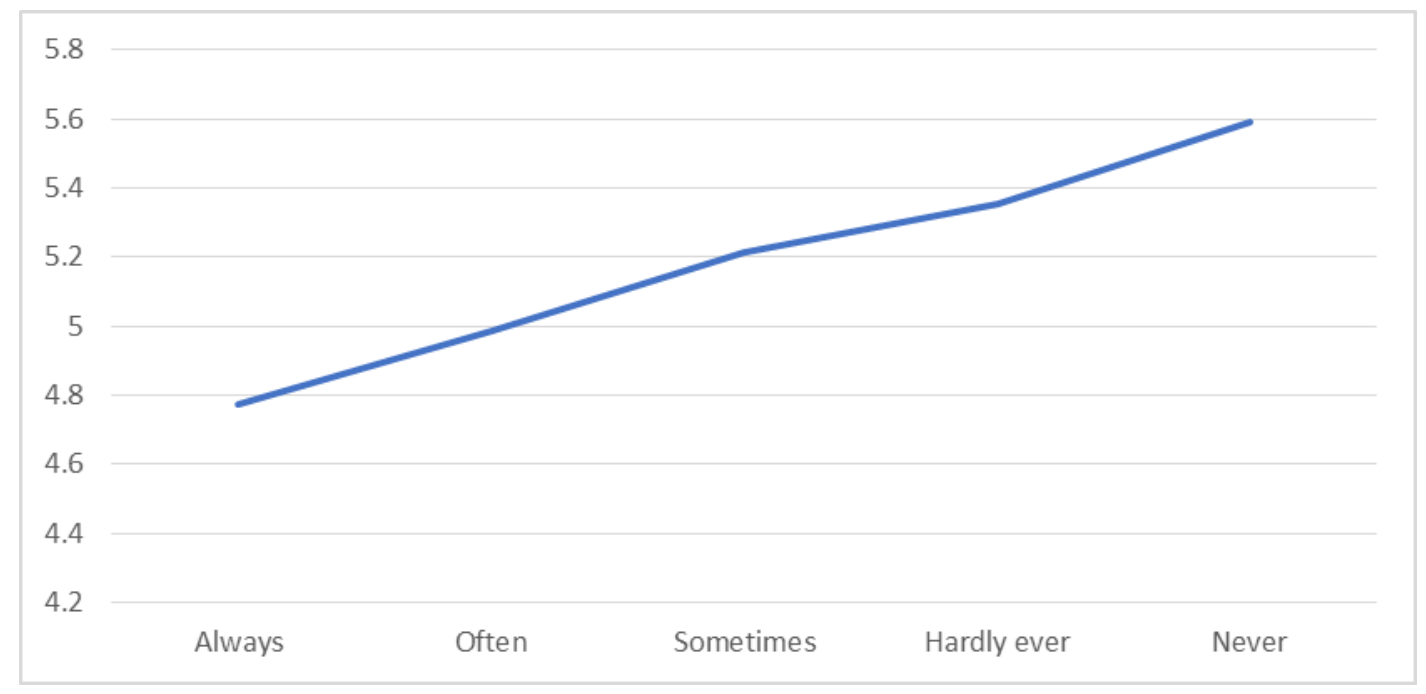

Figure 10. Job Satisfaction Mean Scores: How Often Do You Feel That The Demands Of Your Job Interfere With Your Family Life? 
Table 6. Work-life balance and schedule flexibility variables, by country

\begin{tabular}{|c|c|c|c|c|c|}
\hline \multirow[b]{2}{*}{ Country } & \multicolumn{5}{|c|}{ Variable Beta Coefficients and Significance in Full Model } \\
\hline & $\begin{array}{l}\text { Work } \\
\text { from } \\
\text { Home }\end{array}$ & $\begin{array}{c}\text { Work } \\
\text { Weekends }\end{array}$ & $\begin{array}{l}\text { Schedule } \\
\text { Flexibility }\end{array}$ & $\begin{array}{c}\text { Flexibility } \\
\text { to Deal with } \\
\text { Family } \\
\text { Matters }\end{array}$ & $\begin{array}{c}\text { Work } \\
\text { Interferes } \\
\text { with Family }\end{array}$ \\
\hline Australia & 0.046 & $-0.081 *$ & 0.048 & 0.026 & $0.159 * * *$ \\
\hline Austria & -0.020 & 0.018 & -0.012 & $-0.090^{*}$ & $0.079 *$ \\
\hline Belgium & 0.020 & -0.006 & 0.027 & -0.034 & $0.123 * * *$ \\
\hline Chile & -0.035 & -0.062 & 0.046 & $-0.137^{* *}$ & $0.152^{* *}$ \\
\hline China & -0.074 & 0.022 & 0.014 & -0.009 & 0.107 \\
\hline Taiwan & -0.056 & -0.025 & 0.032 & -0.020 & $0.177 * * *$ \\
\hline Croatia & $0.122 *$ & 0.015 & -0.038 & -0.090 & $0.195 * * *$ \\
\hline Czech Republic & -0.002 & $-0.089^{* *}$ & 0.045 & -0.007 & $0.126^{* * *}$ \\
\hline Denmark & -- & -- & 0.051 & $-0.071^{*}$ & $0.135 * * *$ \\
\hline Estonia & 0.004 & -0.017 & -0.001 & -0.043 & $0.121 * * *$ \\
\hline Finland & -0.045 & 0.013 & 0.048 & 0.028 & $0.121^{* *}$ \\
\hline France & -0.020 & -0.055 & -0.065 & -0.042 & 0.080 \\
\hline Georgia & $0.148 * *$ & -0.018 & 0.031 & 0.053 & $0.139^{* *}$ \\
\hline Germany & 0.026 & -0.057 & 0.044 & -0.060 & $0.122 * * *$ \\
\hline Hungary & 0.040 & -0.020 & -0.054 & -0.035 & $0.135^{* *}$ \\
\hline Iceland & $0.085^{*}$ & $-0.089^{*}$ & -0.007 & -0.027 & $0.109^{* *}$ \\
\hline India & 0.013 & $-0.129 *$ & -0.003 & $-0.229 * * *$ & $0.165^{*}$ \\
\hline Israel & 0.058 & -0.044 & 0.028 & -0.009 & $0.154 * * *$ \\
\hline Japan & -0.024 & -0.050 & 0.048 & 0.000 & 0.054 \\
\hline Latvia & -0.064 & -0.051 & -0.005 & -0.045 & $0.103 * *$ \\
\hline Lithuania & -0.053 & -0.056 & $-0.123^{*}$ & -0.066 & $0.100 *$ \\
\hline Mexico & -0.014 & $-0.098^{*}$ & 0.066 & $-0.113^{*}$ & 0.035 \\
\hline New Zealand & 0.011 & 0.029 & 0.058 & -0.054 & 0.013 \\
\hline Norway & 0.000 & $-0.089^{* *}$ & -0.017 & -0.060 & $0.110^{* *}$ \\
\hline Philippines & $0.101 *$ & -0.003 & 0.059 & -0.003 & -0.036 \\
\hline Poland & -0.004 & 0.065 & -0.001 & 0.003 & 0.027 \\
\hline Russia & -0.036 & 0.015 & -0.022 & -0.008 & $0.109^{* *}$ \\
\hline Slovak Republic & -0.009 & -0.034 & -0.023 & $-0.091^{*}$ & $0.113^{* *}$ \\
\hline Slovenia & -0.036 & 0.055 & $-0.113^{*}$ & $-0.101 *$ & 0.070 \\
\hline South Africa & -0.009 & -0.055 & 0.021 & $-0.084 *$ & 0.067 \\
\hline Spain & 0.007 & -0.023 & -0.033 & -0.050 & 0.050 \\
\hline Suriname & -0.012 & -0.013 & 0.075 & $-0.159 * *$ & 0.077 \\
\hline Sweden & 0.066 & -0.055 & 0.043 & -0.038 & $0.074 *$ \\
\hline Switzerland & -0.025 & 0.027 & 0.067 & -0.060 & $0.079 *$ \\
\hline $\begin{array}{l}\text { United } \\
\text { Kingdom }\end{array}$ & 0.025 & -0.025 & 0.019 & -0.023 & $0.087^{* *}$ \\
\hline United States & -0.002 & -0.012 & 0.034 & -0.048 & $0.065^{*}$ \\
\hline Venezuela & -0.077 & 0.092 & 0.017 & 0.057 & 0.073 \\
\hline All Countries & 0.005 & $-0.023 * * *$ & $0.014 *$ & $-0.036 * * *$ & $0.097 * * *$ \\
\hline
\end{tabular}




\section{Revisiting Work-life Balance Hypotheses}

When looking exclusively at the work-life balance and schedule flexibility variables across countries, we continue to see interesting variations. Table 6 above includes both variable mean scores and standardized beta coefficient and statistical significance for each of work-life balance variables in predicting job satisfaction. Clearly "work interferes with family" has the strongest bet coefficients and is the most consistently statistically significant across the 37 countries included in the 2015 Work Orientations data. "Flexibility to deal with family matters," "Working weekends," and schedule flexibility" were also statistically significant for many countries, as well as in the model including all countries. Interestingly, "work from home," while statistically significant in Croatia, Georgia, Iceland, and the Philippines, was not significant in the model including all countries.

These findings partially support $\mathrm{H} 2 \mathrm{a}, \mathrm{H} 2 \mathrm{~b}, \mathrm{H} 2 \mathrm{c}, \mathrm{H} 2 \mathrm{c}$, and $\mathrm{H} 3$. There are clearly statistically significant cross-national differences in the impact of working from home, working weekends, scheduling flexibility, ability to deal with family matters, and work interfering with family on job satisfaction levels across countries. While each variable is not statistically significant across all countries, they are significant with the expected positive or negative coefficient in some countries, as well as in both the work-life balance model and combined model for all countries.

\section{Discussion and Practical Implications}

Results show that both intrinsic and extrinsic work characteristics, workplace relationships, work-life balance, and scheduling flexibility conditions strongly impact worker job satisfaction. Therefore, it is important for any work organization (such as multinational corporations, global NGOs, local and national governments, and labor unions) to understand that individual workers in different countries face unique country-contextual conditions that impact their experience in the workplace.

The key findings of this study, when all 37 countries are considered in the aggregate, demonstrate the following:

1. Few workers have the option of working from home.

2. Most workers have a regular shift.

3. Workers generally do not perceive that their jobs interfere with family.

4. Work situations are flexible enough to allow workers to take a couple hours off to manage family or personal matters.

These are mostly positive findings. Additionally, job satisfaction increases with schedule flexibility (start and end times), the ability to take time off to handle family matters, and work not interfering with family. The last two variables are already reported to be largely present across countries in this study, although nation-specific factors need for be taken into account.

Examining the gap between the status of work-life balance and what is considered desirable for increased job satisfaction, as determined in this study, suggests managers should consider increasing scheduling flexibility. This might entail offering variability in start and end times, working from home, and split-week schedules. Existing literature supports this suggestion, 
which demonstrates that various flex time options increase job satisfaction and, in particular, improve performance at work and enrichment at home (Carlson et al., 2010). Flexible scheduling also has other desirable effects, such as improved job commitment, performance, organizational citizenship behaviors, better group dynamics, and decreased turnover intent (Allen, 2001; Carlson et al., 2010; Eaton, 2003; Jones et al., 2008; Kossek \& Oseki, 2006; Roehling et al., 2001; Van Dyne, Kossek \& Lobel, 2007).

In spite of almost two decades of research support for these suggestions and the fact that employees indicate they would leave their current jobs for work offering greater scheduling flexibility (Gallup, Inc., 2017), managers do not appear to be increasing flexibility in these ways. Contrarily, managers allowing time off during the day for family matters is decreasing and the percentage of those offering flexible scheduling options is stagnant (Matos et al., 2017).

Also of interest is the finding that intrinsic rewards accounted for the largest variation in job satisfaction in the model. As such, managers may want to consider strategies for increasing intrinsic motivation, which might include recognition programs or nonfinancial incentives, which are associated with increased job satisfaction and self-efficacy (Markham, Scott, \& McKee, 2002; Peterson \& Luthans, 2006). Intrinsic motivation is most impacted by the degree to which employees perceive their work to be meaningful, are able to exercise autonomy, and are connected with others, as captured in Self-Determination Theory (Deci, Koestner, \& Ryan, 1999; Deci \& Ryan, 2002; Ryan \& Deci, 2000; Gagné \& Deci, 2005), and which contributed to job satisfaction in this study.

Extrinsic rewards accounted for the second highest variation. Managers in global contexts need to consider their approaches carefully, as extrinsic rewards may counter intrinsic motivation and make work-related goals less meaningful (Sheldon, Elliot, \& Ryan, 2004). A focus on extrinsic rewards, such as salaries, detracts from focusing on the impact work has (Chamorro-Premuzic, 2013). Other research shows that once a person reaches a certain salary level, around \$75,000 U.S., emotional well-being plateaus (Kahneman \& Deaton, 2010). Salary may have an impact on intrinsic and extrinsic motivation, but this data was not available.

O’Neill, Harrison, Cleveland, Almeida, Stawski, and Crouter (2009) identify three dimensions of a work-life balance culture in organizations: (1) managerial support for work-life balance, (2) perceived negative career consequences of using work-family benefit measures, and (3) organizational time expectations that require employees to sacrifice their family lives. Firms with an employee-friendly work-life balance culture have been called 'Family Supportive Organizations' (Allen, 2001). Companies trying to brand themselves as attractive employers due to their employee-friendly work-life balance culture can use this label of 'Family Supportive Organization' to attract, retain, and develop critical talent in tight labor markets. They can use this label to highlight their employees' high levels of work satisfaction and low turnover intentions.

In our analysis, we observe differences in work flexibility that might be based on labor costs (frequent weekend work in China, the Philippines, Mexico, and India) as well as cultural 
influences (frequent weekend work and low likelihood of work from home in Japan). With rising wages and salaries in some of these emerging economies, it will be interesting to see whether those trends continue in the future or whether these economies join the ranks of countries with high labor costs, such as Austria, Israel, Sweden, and Switzerland, and their labor practices. Similarly, schedule volatility seems another factor which might see comparable developments. Regulatory efforts in various countries (Germany, USA, etc.) to increase work schedule predictability, especially for entry-level employees, might serve as models for countries such as the Philippines and others to ease the burden of work life on employees' family life.

Based on these findings, it might be reasonable to label some companies in Japan, China, the Philippines, Mexico, and India as level 2 and 3 organizations in the O'Neill (2009) hierarchy of work-life balance cultures, while more companies in Austria, Switzerland, and Sweden might qualify as level 1 firms in this pyramid of work-life balance culture order. This could be a critical difference maker in the way countries, not just companies, brand themselves in the global war for talent. Job design differences between countries based on legal frameworks and government-mandated and voluntarily offered employee benefits can help to keep talent in level 1 countries and attract crucial knowledge workers to these highly service-oriented labor markets. This might be a counter force to efforts to level the global playing field to make improvements in international labor standards. Longitudinal developments in this sector of job design and job satisfaction will require continuous monitoring from academics and administrators.

Ever since Smith, Kendall, and Hulin's (1969) job descriptive index and Hackman and Oldham's (1976) job characteristics model of job satisfaction, researchers have made modest variations to this earlier foundational work to develop a variety of job satisfaction models. Among those job satisfaction models still used today, arguably none are as commonly used as the one developed by Kalleberg (1977) and used by Handel (2005) and countless others. In each case, this commonly accepted model has been considered to be widely generalizable across a wide variety of cross-cultural and cross-national contexts. However, as demonstrated previously, Kalleberg (1977) and Handel's (2005) broadly accepted job satisfaction model is not simply duplicable across countries around the world. Rather, what is commonly considered a widely generalizable job satisfaction model actual holds up very differently in countries around the world within varying country contexts, with overall predictability and job satisfaction determinants' significance levels varying considerably across nations. Therefore, researchers should take great caution in comparing results from different job satisfaction studies performed around the world. Rather, a new and expanded model of job satisfaction, one that takes into account country-contextual differences, is vitally needed.

\section{Future Research}

This research has empirically demonstrated clear cross-national differences in job satisfaction and its determinates, specifically examining new work-life balance and schedule flexibility variables. The question remains, what are the causes behind cross-national determinants of job satisfaction? Cross-cultural researchers would suggest that any such differences would all 
be due to cultural differences between countries. However, the limited research that explores work quality characteristics and job satisfaction from a cross-cultural perspective has largely failed to show how countries with similar cultural orientations still experience significant differences and how countries with different cultural orientations still experience similarities.

The question remains, what are the causes for these country differences. More specifically, what are the key country-level contextual and global-macro variables driving these country differences in job characteristics and perceived worker satisfaction (which is of increasing relevance in the age of an ever more globalized economy and hyper-competitive global marketplace)? Existing research cannot answer these and other related questions. Like many work attitudes, job satisfaction is a dynamic construct that changes in response to personal and environmental conditions. Monitoring job satisfaction over time and in different contexts will allow one to better examine and understand the salient factors that affect job satisfaction.

To be able to examine these questions and further explore possible explanations and mechanisms by which these relationships unfold, future research needs to undertake efforts:

1. to better understand the linkage between various job quality characteristics and worker satisfaction;

2. to better understand how worker satisfaction relates to many other important organizational, institutional, economic, social, and individual outcomes;

3. to better understand cross-national differences in these relationships and what these differences mean for various stakeholders (e.g. employers, employees, labor unions, governments, etc.).;

4. to better understand gender differences in perceptions of WLB, job satisfaction, and the effects labor regulations in various countries have on male and female work commitments;

5. to better understand the often detrimental consequences (family strain, divorce, health consequences and expenses, etc.) of poor WLB practices across countries;

6. to better explore with new methods and understand whether cultural aspects across various countries actually have meaningful impact on how jobs are designed, how work is executed, how employees respond to legal frameworks of work, and how these elements impact WLB, job satisfaction, turnover intentions, labor costs, etc.

\section{Conclusion}

This research effort has produced meaningful insights into the role of WLB and work scheduling flexibility in predicting global comparative job satisfaction. We caution, however, to simply generalize our findings to be representative for entire nations. Our study, data set, and methodology faced a few limitations. Even though we used data from stratified random samples within each country, and sample sizes are, on average, sufficient for academic 
research, we cannot drill down to industry levels or variables in individual organizations specific to where each respondent works, such as organization type, size, or seniority levels.

Similarly, we have to face the reality that we, in part, have used terminology for cultures to exemplify entire nations, which is not entirely representative. Cultural and legal differences within and across nations have been neglected. However, this is often common practice in international human resource management research since Hofstede (1980).

The most critical contribution of this study was country-specific variations in antecedents to job satisfaction. This is the first study to examine the impact of various intrinsic, extrinsic, and workplace relations variables cross-nationally. National workplace factors can and do impact job satisfaction. Cultural variations are not sufficient to explain these differences as countries with similar cultural orientations demonstrate significant differences and those with different cultural orientations experience similarities. Further research is needed in this area. Meanwhile, employers are encouraged to implement strategies to increase job satisfaction and WLB through flexible scheduling and intrinsic and extrinsic rewards, and by so doing, positively impact their companies. Greater productivity; lower turnover (intentions); decreased organizational, career, and personal costs; increased company, family, individual, and professional stability; and even decreased environmental impact due to fewer commuter miles driven as a result of implemented flexible work arrangements are anticipated results of the human resource practices proposed in this paper. Additionally, improved global labor market balance through decreased immigration with resulting optimized national economic development could be international business outcomes due to more market-sensitive employment practices. This article provides a map for domestically and internationally operating organizations to accomplish these potential results and make contributions to greater job and life satisfaction of their employees and beyond.

\section{References}

Allen, T. D. (2001). Family-supportive work environments: The role of organizational perceptions. Journal of Vocational Behavior, 58(3), 414-435. https://doi.org/10.1006/jvbe.2000.1774

Allen, T. D., Herst, D. E. L., Bruck, C. S., \& Sutton, M. (2000). Consequences associated with work-to-family conflict: A review and agenda for future research. Journal of Occupational Health Psychology, 59(2), 278-308. https://doi.org/10.1037/1076-8998.5.2.278

Appelbaum, S., \& Kamal, R. (2000). An analysis of the utilization and effectiveness of nonfinancial incentives in small business. Journal of Management Development, 19(9), 733-763. https://doi.org/10.1108/02621710010378200

Argyle, M. (1989). The social psychology of work. Harmondsworth, UK: Penguin.

Becker, P. E., \& Moen, P. (1999). Scaling back: Dual-career couples' work-family strategies. Journal of Marriage and the Family, 61(4), 995-1007. https://doi.org/10.2307/354019

Blau, G. (1994). Developing and testing a taxonomy of lateness behavior. Journal of Applied Psychology, 79(6), 959-970. https://doi.org/10.1037/0021-9010.79.6.959 


\section{Macrothink}

International Journal of Human Resource Studies

ISSN 2162-3058

2019, Vol. 9, No. 2

Brough, P., Holt, J., Bauld, R., Biggs, A., \& Ryan, C. (2008). The ability of work-life balance policies to influence key social/organisational issues. Asian-Pacific Journal of Human Resources, 46(3), 261-274. https://doi.org/10.1177/1038411108095758

Brough, P., O’Driscoll, M. P., \& Biggs, A. (2009). Parental leave and work-family balance among employed parents following childbirth: An exploratory investigation in Australia and New Zealand. New Zealand Journal of Social Sciences Online, 4(1), 71-87. https://doi.org/10.1080/1177083X.2009.9522445

Brough, P., Timms, C., O’Driscoll, M. P., Kalliath, T., Siu, O. L., Sit, C., \& Lo, D. (2014). Work-life balance: A longitudinal evaluation of a new measure across Australia and New Zealand workers. International Journal of Human Resource Management, 25(19), 2724-2744. https://doi.org/10.1080/09585192.2014.899262

Byrne, B. M., \& Campbell, T. L. (1999). Cross-cultural comparisons and the presumptions of equivalent measurement and theoretical structure: A look beneath the surface. Journal of Cross-Cultural Psychology, 30(5), 555-574. https://doi.org/10.1177/0022022199030005001

Carlson, D. S., Grzywacz, J. G., \& Kacmar, K. M. (2010). The relationship of schedule flexibility and outcomes via the work-family interface. Journal of Managerial Psychology, 25(4), 330-355. https://doi.org/10.1108/02683941011035278

Carlson, J. H., \& Mellor, S. (2004). Gender-related effects in the job-design-job-satisfaction relationship: an international approach. Sex Roles: A Journal of Research, 51(3-4), 237-247. https://doi.org/10.1177/0022022199030005001

Cegarra-Leiva, D., Sanchez-Vidal, M. E., \& Cegarra-Navarro, J. G. (2012). Work life balance and the retention of managers in Spanish SMEs. International Journal of Human Resource Management, 23(1), 91-108. https://doi.org/10.1080/09585192.2011.610955

Chamorro-Premuzic, T. (2013, April 10). Does money really affect motivation? A review of the research. Harvard Business Review. Retrieved from https://hbr.org/2013/04/does-money-really-affect-motiv

Chen, G., Ployhart, R. E., Thomas, H. C., Anderson, N. \& Bliese, P. D. (2011). The power of momentum: A new model of dynamic relationships between job satisfaction change and turnover intentions. Academy of Management Journal, 54(1), 159-181.

Cheung, G. W., \& Rensvold, R. B. (2000). Assessing extreme and acquiescence response sets in cross-cultural research using structural equations modeling. Journal of Cross-Cultural Psychology, 31(2), 160-186. https://doi.org/10.1177/0022022100031002003

Clark, A. E., \& Oswald, A. J. (1996). Satisfaction and comparison income. Journal of Public Economics, 61(3), 359-381. https://doi.org/10.1016/0047-2727(95)01564-7

Daniel, S., \& Sonnentag, S. (2016). Crossing the borders: the relationship between boundary management, work-family enrichment and job satisfaction. The International Journal of Human Resource Management, 4(27), 407-426. https://doi.org/10.1080/09585192.2015.1020826 
Deci, E. L., Koestner, R., Ryan, R. M. (1999). A meta-analytic review of experiments examining the effects of extrinsic rewards on intrinsic motivation. Psychological Bulletin, 125(6), 627-668. https://doi.org/10.1037/0033-2909.125.6.627

Deci, E., \& Ryan, R. (Eds.) (2002). Handbook of self-determination research. Rochester, NY: University of Rochester Press.

Diener, C., Diener, E., \& Diener, M. (1995). Factors predicting the subjective well being of nations. Journal of Personality Social Psychology, 69(5), 851-864. https://doi.org/10.1037/0022-3514.69.5.851

Eaton, S. (2003). If you can use them: Flexibility policies, organizational commitment, and perceived performance. Industrial Relations, 42(2), 145-167. https://doi.org/10.1111/1468-232X.00285

Facer, R. L., \& Wadsworth, L. (2008). Alternative work schedules and work-family balance. Review of Public Personnel Administration, 28(2), 166-177. https://doi.org/10.1177/0734371X08315138

Fischer, R. (2004). Standardization to account for cross-cultural response bias: A classification of score adjustment procedures and review of research in JCCP. Journal of Cross-Cultural Psychology, 35(3), 263-282. https://doi.org/10.1177/0022022104264122

Freeman, R. (1978). Job satisfaction as an economic variable. American Economic Review, 68(2), 135-41.

Gagné, M., \& Deci, E. L. (2005). Self-determination theory and work motivation. Journal of Organizational Behavior, 26(4), 331-362. https://doi.org/10.1002/job.322

Gallup, Inc. (2017). State of the American workplace. Washington, DC: Gallup, Inc.

Garrido, M. J., Perez, P., \& Anton, C. (2005). Determinants of sales manager job satisfaction: Ananalysis of Spanish industrial firms. International Journal of Human Resource Management, 16(1), 1934-1954. https://doi.org/10.1080/09585190500298776

Gatrell, C. J., Burnett, S. B., Cooper, C. L., \& Sparrow, P. (2013). Work-life balance and parenthood: A comparative review of definitions equity and enrichment. International Journal of Management Review, 300-316. https://doi.org/10.1111/j.1468-2370.2012.00341.x

Greenhaus J. H., \& Beutell, N. J. (1985). Sources of conflict between work and family roles. Academic Management Review, 10(1), 76-88. https://doi.org/10.5465/amr.1985.4277352

Greenhaus, J. H., \& Kossek, E. E. (2014). The contemporary career: a work-home perspective. Annual Review of Organizational Psychology and Organizational Behavior, 1(1), 361-388. https://doi.org/10.1146/annurev-orgpsych-031413-091324

Greenhaus, J. H., \& Powell, G. N. (2006). When work and family are allies: A theory of work-family enrichment. Academy of Management Review, 31(1), 72-92. https://doi.org/10.5465/amr.2006.19379625 


\section{MInstitute Macrink $_{\text {Insthe }}$}

International Journal of Human Resource Studies

ISSN 2162-3058

2019, Vol. 9, No. 2

Griffeth, R. W., Hom, P. W., \& Gaertner, S. (2000). A meta-analysis of antecedents and correlates of employee turnover: Update, moderator tests, and research implications for the next millennium. Journal of Management, 26(3), 463-488. https://doi.org/10.1177/014920630002600305

Hackman, J. R., \& Oldham, G. R. (1976). Motivation through the design of work: Test of a theory. Organizational Behavior and Human Performance, 16(2), 250-279. https://doi.org/10.1016/0030-5073(76)90016-7

Hamermesh, D. S. (2001). The changing distribution of job satisfaction. Journal of Human Resources, 36(1), 1-30. https://doi.org/10.2307/3069668

Handel, M. J. (2005). Trends in perceived job quality, 1989 to 1998. Work and Occupations, 32(1), 66-94. https://doi.org/10.1177/0730888404271901

Hanson, G. C., Hammer, L. B, \& Colton, C. L. (2006). Development and validation of a multidimensional scale of perceived work-family positive spillover. Journal of Occupational Health Psychology, 11(3), 249-265. https://doi.org/10.1037/1076-8998.11.3.249

Higgins, C., Duxbury, L., Julien, M. (2014). The relationship between work arrangements and work-family conflict. Work, 48(1), 69-81.

Hodson, R. (2002). Demography or respect? Work group demography versus organizational dynamics as determinants of meaning and satisfaction at work. The British Journal of Sociology, 53(2), 291-317. https://doi.org/10.1080/00071310220133359

Hofstede, G. (1980). Culture's consequences: International differences in work-related values. Beverly Hills, CA: Sage.

Hunt, J. W., \& Saul, P. N. (1975). The Relationship of age, tenure, and job satisfaction in males and females. Academy of Management Journal, 18(4), 690-702.

Ilies, R. Wilson, K. S., \& Wagner, D. T. (2009). The spillover of daily job satisfaction onto employees' family lives: The facilitating role of work-family integration. Academy of Management Journal, 52(1), 87-102. https://doi.org/10.5465/amj.2009.36461938

Ilies, R., Liu, X. Y., Liu, Y, \& Zheng, X. (2017). Why do employees have better family lives when they are highly engaged at work? Journal of Applied Psychology, 102(6), 956-970. https://doi.org/10.1037/ap10000211

Iliescu, D., Ispas, D. Sulea, C., \& Ilie, A. (2015). Vocational fit and counterproductive work behaviors: A self-regulation perspective. Journal of Applied Psychology, 100(1), 21-39. https://doi.org/10.1037/a0036652

Jones, B. L., Scovile, P., Hill, E. J., Childs, G., Leishman, J. M., \& Nally, K. S. (2008). Perceived versus used workplace flexibility in Singapore: Predicting work-family fit. Journal of Family Psychology, 22(5), 774-783. https://doi.org/10.1037/a0013181

Judge, T. A., Thoresen, C. J., Bono, J. E., \& Patton, G. K. (2001). The job satisfaction-job performance relationship: A qualitative and quantitative review. Psychological Bulletin, 
127(3), 376-407. https://doi.org/10.1037/0033-2909.127.3.376

Jung, K. H., \& Moon, M. J., \& Hahm, S. D. (2007). Do age, gender, and sector affect job satisfaction? Results from the Korean labor and income panel data. Review of PublicPersonnel Administration, $\quad 27(2), \quad 125-146$. https://doi.org/10.1177/0734371X06289229

Kahneman, D., \& Deaton, A. (2010). High income improves evaluation of life but not emotional well-being. Proceedings of the National Academy of Science of the United States of America, 107(38), 16489-16493. https://doi.org/10.1073/pnas.1011492107

Kalleberg, A. (1977). Work values \& job rewards: A theory of job satisfaction. American Sociological Review, 42(1), 124-43. https://doi.org/10.2307/2117735

Kalleberg, A. L., \& Loscocco, K. A. (1983). Aging, values and rewards explaining age differences in job satisfaction. American Sociological Review, 48(1), 78-90. https://doi.org/10.2307/2095146

Koning, C. (2014). Does self-scheduling increase nurses' job satisfaction? An integrative literature review. Nursing management, 21(6), 24-28. https://doi.org/10.7748/nm.21.6.24.e1230

Kossek, E., \& Ozeki, C. (1998). Work-family conflict, policies, and the job-life satisfaction relationship: A review and directions for organizational behavior-human resources research. Journal of Applied Psychology, 83(2), 139-149. https://doi.org/10.1037/0021-9010.83.2.139

Kreiner, G. E., Hollensbe, E. C., \& Sheep, M. L. (2009). Balancing borders and bridges: Negotiating the work-home interface via boundary work tactics. Academy of Management Journal, (52)4, 704-730. https://doi.org/10.5465/amj.2009.43669916

Lee, T. (1998). Job satisfaction leads to turnover. Journal of Business and Psychology, 29(3), 263-271. https://doi.org/10.1007/BF01014043

Markham, S. E., Scott, K. D., \& McKee, G. H. (2002). Recognizing good attendance: A longitudinal, quasi-experimental field study. Personnel Psychology, 55(3), 639-660. https://doi.org/10.1111/j.1744-6570.2002.tb00124.x

Matos, K. \& Galinsky, E., (2011). Workplace flexibility in the United States: A status report. Retrieved from http://familiesandwork.org/downloads/WorkplaceFlexibilityinUS.pdf

Matos, K., Galinsky, E., \& Bond, J. T. (2017). National study of employers. Alexandria, VA: Society for Human Resource Management. Retrieved from https://www.shrm

McNall, L. A., Masuda, A. D., \& Nicklin, J. M. (2010). Flexible work arrangements, job satisfaction, and turnover intentions: the mediating role of work-to-family enrichment. Journal of Psychology, 144(1), 61-81. https://doi.org/10.1080/00223980903356073

Michel, R. D. J., \& Michel, C. E. J. (2012). Faculty satisfaction and work-family enrichment: The moderating effect of human resource flexibility. Social and Behavioral Science, 46(1), 5168-5172. https://doi.org/10.1016/j.sbspro.2012.06.402 
O'Driscoll, M. P., Brough, P., \& Haar, J. (2011). The work-family nexus and small-medium enterprises: Implications for worker well-being. In E. K. Kelloway and C. L. Cooper (Eds.), Occupational health and safety for small and medium sized enterprises (pp. 106-128). Cheltenham, UK: Edward Elgar. https://doi.org/10.4337/9780857938701.00011

O'Keefe, P. A. (2014, September 7). Liking work really does matter. The New York Times, p. 12.

O’Neill, J. W., Harrison, M. K., Cleveland, J., Almeida, D., Stawski, R., \& Crouter, A.C. (2009). Work-family climate, organizational commitment, and turnover: Multilevel contagion effects on leaders. Journal of Vocational Behaviour, 74(1), 18-29. https://doi.org/10.1016/j.jvb.2008.10.004

Pattusamy, M., \& Jacob, J. (2017). A test of Greenhaus and Allen (2011) model on work-family balance. Current Psychology, 36(2), 193-202. https://doi.org/10.1007/s12144-015-9400-4

Peterson, S. J., \& Luthans, F. (2006). The impact of financial and nonfinancial incentives on business unit outcomes over time. Journal of Applied Psychology, 91(1), 156-165. https://doi.org/10.1037/0021-9010.91.1.156

Roehling, P. V., Roehling, M. V. \& Moen, P. (2001). The relationship between work-life policies and practices and employee loyalty: A life course perspective. Journal of Family and Economic Issues, 22(2), 141-70. https://doi.org/10.1023/A:1016630229628

Ryan, R., \& Deci, E. (2000). Self-determination theory and the facilitation of intrinsic motivation, social development, and well-being. American Psychologist, 55(1), 68-78. https://doi.org/10.1037/0003-066X.55.1.68

Saltzstein, A, Ting Y., \& Saltzstein, G. (2001). Work-life balance and job satisfaction: The impact of family-friendly policies on attitudes of federal government employees. Public Administration Review, 61(4), 452-466. https://doi.org/10.1111/0033-3352.00049

Schooreel, T., Shockley, K. M., \& Verbruggen, M. (2017). What if people's private life constrained their career decisions? Examining the relationship between home-to-career interference and career satisfaction. Career Development International, 22(2), 124-141. https://doi.org/10.1108/CDI-03-2016-0037

Sheldon, K. M., Elliot, A. J., \& Ryan, R. M. (2004). Self-concordance and subjective well-being in four cultures. Journal of Cross-Cultural Psychology, 35(2), 209-223. https://doi.org/10.1177/0022022103262245

Smith, P. C., Kendall, L. M., \& Hulin, C. L. (1969). The measurement of satisfaction in work and retirement. Chicago: Rand McNally.

Sousa-Pouza A., \& Sousa-Pouza A. A. (2000). Well-being at work: A cross-national analysis of the levels and determinants of job satisfaction, Journal of Socio-Economics, 29(6), 517-538. https://doi.org/10.1016/S1053-5357(00)00085-8 


\section{Mll Macrothink}

International Journal of Human Resource Studies ISSN 2162-3058 2019, Vol. 9, No. 2

Spector, P. (1997). Job satisfaction: Application, assessment, causes and consequences. Thousand Oaks, CA: Sage.

Taylor, J., \& Westover, J. (2011). Job satisfaction in the public service. The effects of public service motivation, work-place attributes and work relations. Public Management Review. 13(5), 731-751. https://doi.org/10.1080/14719037.2010.532959

Tietjen, M. A., \& Myers, R. M. (1998). Motivation and job satisfaction. Management Decision, 36(4), 226-231. https://doi.org/10.1108/00251749810211027

Van Dyne, L., Kossek, E. E., \& Lobel, S. (2007). Less need to be there: Cross level effects of work practices that support work-life flexibility and enhance group processes and group level OCB. Human Relations, 60(8), 1123-1154. https://doi.org/10.1177/0018726707081657

Voydanoff, P. (2005), Toward a conceptualization of perceived work-family fit and balance: A demands and resources approach. Journal of Marriage and Family, 67(4), 822-836. https://doi.org/10.1111/j.1741-3737.2005.00178.x

Westover, J. H. (2008a). A cross-national analysis of job quality characteristics and perceived job satisfaction in a changing world economy: Implications for public administrators managing in a multicultural workforce. International Review of Public Administration, 13(2), 129-144. https://doi.org/10.1080/12294659.2008.10805126

Westover, J. H. (2008b). Potential impacts of globalization on changing job quality and worker satisfaction: A descriptive cross-national comparative examination. Journal of Global Business Management, 14(1), 19-26.

Westover, J. H. (2010a). Global shifts: Changing job quality and job satisfaction: Determinants in socialist and post-socialist Hungary. International Journal of Social Economics, 37(2), 84-100. https://doi.org/10.1108/03068291011007228

Westover, J. H. (2010b). Global economic shifts impacting the perceived importance of various intrinsic and extrinsic job characteristics and overall job satisfaction. The International Journal of Knowledge, Culture, and Change Management, 10(1), 137-149. https://doi.org/10.18848/1447-9524/CGP/v10i01/49872

Westover, J. H. (2012a). Comparative international differences in intrinsic and extrinsic job quality characteristics and worker satisfaction, 1989-2005. International Journal of Business and Social Science, 3(7), 1-15.

Westover, J. H. (2012b). Comparative welfare state impacts on work quality and job satisfaction: A cross-national analysis. International Journal of Social Economics, 39(7), 502-525. https://doi.org/10.1108/03068291211231687

Westover, J. H. (2012c). The job satisfaction-gender paradox revisited: A cross national look at gender differences in job satisfaction, 1989-2005. Journal of Global Responsibility, 3(2), 263-277. https://doi.org/10.1108/20412561211260557 


\section{Macrothink}

International Journal of Human Resource Studies ISSN 2162-3058 2019, Vol. 9, No. 2

Westover, J. H. (2013a). The impact of country context on employee job satisfaction: An application of the world-systems framework. International Journal of Management, 30(2), 451-463.

Westover, J. H. (2013b). The impact of comparative state-directed development on working conditions and employee satisfaction. Journal of Management and Organization, 19(4), 498-518.

Westover, J. H. (2016a). The international political economy of worker satisfaction: A cross national HLM analysis. Evidence-Based HRM: A Global Forum for Empirical Scholarship, $4(3), 116-143$.

Westover, J. H. (2016b) Shifting societal attitudes and values in Belarus, 1989-2015. The International Journal of Interdisciplinary Organizational Studies, 11(3), 1-26.

Westover, J. H., \& Taylor, J. (2010). International differences in job satisfaction: The effects of public service motivation, rewards and work relations. International Journal of Productivity and Performance Management, 59(8), 811-828.

Westover, J. H., Doxey, T., \& Spencer, M. (2013). European country Contextual Differences Impacting job quality characteristics and worker satisfaction. Organizational Cultures: An International Journal, 12(3), 1-17.

Wright, B., \& Kim, S. (2004). Participation's influence on job satisfaction: The importance of job characteristics. Review of Public Personnel Administration, 24(1), 18-40.

Ybema, J. F., Smulders, P. G. W., \& Bongers, P. M. (2010). Antecedents and Consequences of employee absenteeism: A longitudinal perspective on the role of job satisfaction and burnout. European Journal of Work and Organizational Psychology, 19(1), 102-124.

\section{Appendix 1: OLS Regression Results of Job Satisfaction and Main Study Variables by} Country, 2015

Table 7-Continued

\begin{tabular}{|c|c|c|c|c|c|c|c|c|c|c|c|c|c|c|}
\hline VARIABLE & 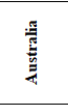 & 辤 & 袁 & हूँ & 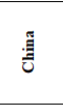 & 竎 & 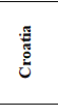 & 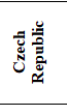 & 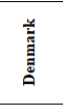 & 畄 & 胥 & 荙 & 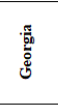 & 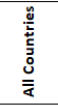 \\
\hline Interesting Work & $0.305^{* * *}$ & $0.104^{*}$ & $0.379^{* * * *}$ & $0.170^{* * * *}$ & $0.225 *$ & $0.105^{* * * *}$ & $0.374 * * z$ & $0.306^{* * *}$ & $0.441^{* * *}$ & $0.211^{* * z}$ & $0.41^{* * * *}$ & $0.34^{7 * * *}$ & $0.285^{5 * *}$ & $0.287 \cdots$ \\
\hline $\begin{array}{l}\text { Job Autonomy } \\
\text { Help Others }\end{array}$ & $\begin{array}{l}-0.001 \\
-0.068\end{array}$ & $\begin{array}{l}0.034 \\
0.112^{* *}\end{array}$ & $\begin{array}{l}0.048 \\
0.027\end{array}$ & $\begin{array}{l}-0.123^{*} * \\
-0.008\end{array}$ & $\begin{array}{l}-0.005 \\
0.039\end{array}$ & $\begin{array}{l}-0.057^{*} \\
0.088 * *\end{array}$ & $\begin{array}{l}-0.039 \\
0.019\end{array}$ & $\begin{array}{l}0.082^{*} \\
0.017\end{array}$ & $\begin{array}{l}0.003 \\
0.019\end{array}$ & $\begin{array}{l}0.087^{*} \\
0.013\end{array}$ & $\begin{array}{l}0.021 \\
0.226\end{array}$ & $\begin{array}{l}0.035 \\
0.080\end{array}$ & 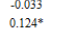 & $0.0199^{*}$ \\
\hline $\begin{array}{l}\text { Help Uthers } \\
\text { Job Useful to Society }\end{array}$ & $0.0 .135^{* *}$ & 0.027 & $0.075^{*}$ & $0.154^{* *}$ & -0.033 & 0.009 & 0.091 & 0.019 & -0.047 & 0.028 & 0.025 & -0.031 & -0.107 & $0.037 \cdots$ \\
\hline Job Security & $0.093^{* *}$ & $0.117^{* *}$ & 0.011 & 0.074 & 0.120 & $0.102^{2 * *}$ & 0.094 & $0.084^{* *}$ & $0.109^{* * z}$ & 0.020 & $0.069^{*}$ & -0.013 & 0.077 & $0.063 \cdots$ \\
\hline Pay & $0.121^{* * *}$ & $0.127^{7 * z=}$ & $0.071^{*}$ & 0.086 & 0.135 & $0.109 * s=$ & $0.135^{*}$ & $\begin{array}{l}0.076^{x} \\
0.5 y\end{array}$ & -0.009 & $0.197^{2 * z 8}$ & $0.135^{* * *}$ & $0.122^{* *}$ & $0.361^{* * z}$ & $0.098 \%$ \\
\hline Promotional Opportunities & 0.070 & $0.106^{* *}$ & $0.097 \cdots$ & 0.074 & -0.036 & -0.021 & 0.031 & $0.087^{*}$ & $0.129^{* * *}$ & 0.042 & 0.060 & $0.106^{*}$ & -0.004 & $0.057 \cdots$ \\
\hline Physical Effort & 0.018 & -0.063 & 0.019 & -0.071 & 0.013 & 0.013 & $0.129^{*}$ & 0.037 & $0.100^{* *}$ & -0.046 & 0.001 & 0.013 & -0.046 & 0.005 \\
\hline Work Stress & $-0.193^{3 * *}$ & $-0.065^{*}$ & $-0.100^{7 * z}$ & $-0.083^{*}$ & -0.049 & $-0.086^{* *}$ & -0.021 & $-0.123^{3 * z}$ & -0.051 & $\begin{array}{l}-0.014 \\
-0.014\end{array}$ & $-0.163^{3 * *}$ & $-0.123^{* *}$ & -0.058 & $-0.086 \cdots$ \\
\hline Relations with Cowo & 0.023 & $0.1177^{* *}$ & $0.055^{*}$ & 0.056 & 0.096 & $0.134^{* \cdots *}$ & 0.095 & $0.130^{* * *}$ & $0.162^{2 * *}$ & $0.170^{* * *}$ & $0.070^{*}$ & $0.144^{* * *}$ & 0.043 & $0.085 \cdots$ \\
\hline $\begin{array}{l}\text { Relations with Manag } \\
\text { Relater }\end{array}$ & $0.290^{* 2 * 3}$ & $0.198^{* z z z}$ & 0.225 & $0.167^{* z * z}$ & 0.116 & $0.183^{* * s}$ & $0.223^{* 3 z}$ & $0.1177^{* * 8}$ & $0.130^{* z z}$ & $0.147^{7 * z}$ & $0.253^{* * 8 *}$ & $0.259^{8 * z}$ & 0.087 & $0.225 \cdots$ \\
\hline Contact with Others & 0.064 & -0.006 & 0.043 & 0.022 & -0.010 & -0.008 & 0.063 & 0.060 & $0.082^{*}$ & 0.031 & 0.012 & -0.011 & -0.037 & 0.01 \\
\hline $\begin{array}{l}\text { Contact with } \\
\text { Discriminated }\end{array}$ & 0.055 & $0.081^{*}$ & 0.001 & $0.094^{*}$ & -0.060 & 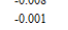 & 0.044 & 0.044 & $0.067^{*}$ & 0.057 & -0.022 & -0.021 & -0.001 -0.031 & $0.037 \cdots$ \\
\hline $\begin{array}{l}\text { Harassed at Work } \\
\text { Hark }\end{array}$ & 0.003 & -0.023 & 0.006 & $\begin{array}{l}.0 .042 \\
-0.012\end{array}$ & 0.025 & 0.000 & 0.026 & 0.005 & 0.009 & -0.010 & 0.011 & 0.015 & 0.100 & $0.019 \cdots$ \\
\hline Work from & & & & & & & & -0.002 & & & & & & \\
\hline $\begin{array}{l}\text { Work trom Hor } \\
\text { Work Weekend }\end{array}$ & $-0.081^{*}$ & 0.0218 & -0.006 0.020 & $\begin{array}{l}-0.032 \\
-0.062\end{array}$ & 0.022 & 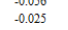 & 0.015 & $\begin{array}{l}-0.002 \\
-0.098=z\end{array}$ & - & -0.017 0.017 & 0.013 & $\begin{array}{l}-0.020 \\
-0.055\end{array}$ & -0.018 & $\begin{array}{c}0.0003 \cdots \\
-0.023-\cdots\end{array}$ \\
\hline $\begin{array}{l}\text { Work W } \\
\text { Schedul }\end{array}$ & $\begin{array}{l}-0.0318 \\
0.048\end{array}-30$ & $\begin{aligned} 0.018 \\
-0.012\end{aligned}$ & 0.027 & 0.046 & 0.014 & $\begin{array}{l}-0.032 \\
0.032\end{array}$ & -0.038 & 0.045 & 0.051 & $\begin{array}{l}-0.001 \\
-0.001\end{array}$ & 0.048 & -0.065 -0.035 & 0.031 & $0.014^{*}$ \\
\hline $\begin{array}{l}\text { Schedule Hiexullity } \\
\text { Fexibility to Deal with Family }\end{array}$ & 0.026 & $\begin{array}{c}-0.012 \\
-0.090^{*}\end{array}$ & -0.034 & 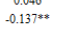 & -0.009 & $\begin{array}{l}-.032 \\
-0.020 \\
-\end{array}$ & $\begin{array}{l}-0.0 .098 \\
-0.090\end{array}$ & $\begin{array}{l}-0.007 \\
-0.007\end{array}$ & $\begin{array}{c}.0 .071^{*} \\
-\end{array}$ & $\begin{array}{c}-0.0013 \\
-0.043\end{array}$ & 0.028 & $\begin{array}{l}-0.0632 \\
-0.042\end{array}$ & 0.053 & $\begin{array}{c}-0.036^{\circ} \cdots \\
-{ }_{0}\end{array}$ \\
\hline $\begin{array}{l}\text { Hexibility to Deal with Family } \\
\text { Work Interferes with Family }\end{array}$ & $0.159=8$ & $\begin{array}{l}0.0 .079^{*} \\
0.45\end{array}$ & $0.123^{* * * *}$ & $0.152^{2 s}$ & 0.107 & 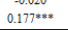 & - & 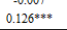 & $\begin{array}{l}0.135^{* * * *} \\
0.04\end{array}$ & $0.121^{* s * z}$ & $0.121^{1 * 8}$ & 0.080 & $0.139 g^{*}$ & $\begin{array}{l}0.0367 \cdots \\
0.097 \cdots\end{array}$ \\
\hline Gender & -0.013 & 0.004 & 0.012 & -0.043 & -0.032 & 0.021 & 0.108 & 0.048 & 0.001 & 0.038 & 0.010 & -0.022 & $0.125^{*}$ & 0.005 \\
\hline & 0.0 & $-0.071^{*}$ & 0.0 & 0.0 & & & -0.021 & $0.094^{* *}$ & & $0.109^{* * * *}$ & & & 0.038 & $0.033 \cdots$ \\
\hline Education & -0.005 & $-0.085^{*}$ & $-0.091^{* *}$ & 0.033 & -0.068 & -0.04 & 0.06 & -0.048 & 0.007 & 0.00 & 0.000 & -0.0 & -0.028 & $-0.045 \cdots$ \\
\hline Marital Status & -0.043 & $-0.099 *$ & -0.020 & .0.007 & $.0 .235 \cdots$ & .0 .06 & .0 .1 & 0.00 & $-0.076^{*}$ & -0.0 & 0.037 & & 0.028 & $-0.028 \cdots$ \\
\hline Size of Family & -0.033 & -0.038 & -0.004 & 0.019 & 0.061 & -0.0 & -0.040 & 0.038 & -0.046 & -0.0 & 0.014 & 0.030 & -0.080 & -0.007 \\
\hline Work Hour & 0.042 & $0.071^{*}$ & $0.074^{* *}$ & 0.107 & -0.0 & $-0.02-3$ & 0.0 & -0.00 & 0.030 & & -0.04 & & -0.012 & 006 \\
\hline Job Clas. & -0.033 & 0.027 & -0.009 & 0.03 & 0.036 & $-0.087 * *$ & .0 .0$. & -0.02 & 0.034 & -0.0 & 0.09 & 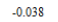 & 0.0 & .0 .009 \\
\hline Supervi & 0.012 & 0.006 & 0.027 & -0.012 & -0.120 & -0.03 & .0 .0 & 0.00 & 0.045 & 0.0 & -0.03 & & -0.076 & -0.004 \\
\hline Employ & 0.000 & 0.001 & -0.023 & 0.015 & -0.024 & 0.032 & -0.106 & $-0.068^{*}$ & 0.037 & 0.007 & -0.026 & 0.022 & -0.073 & 0.008 \\
\hline Public/Private Organization & -0.013 & -0.061 & 0.004 & .0 .009 & -0.094 & -0.024 & $-0.108^{*}$ & -0.007 & -0.007 & 0.019 & -0.002 & .0.057 & -0.041 & $-0.028 \cdots$ \\
\hline & 437 & 551 & 865 & 435 & 256 & 1099 & 215 & 656 & 547 & 578 & 464 & 462 & 306 & 18,716 \\
\hline$\underset{F}{\text { ADJ.R-SQUARED }}$ & $\begin{array}{c}0.626 \\
0.618=x\end{array}$ & $\begin{array}{c}0.523 \\
0.72=0\end{array}$ & $\begin{array}{c}0.533 \\
3490 * x\end{array}$ & $\begin{array}{l}0.374 \\
0.95 * x\end{array}$ & 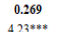 & 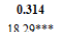 & $\begin{array}{l}0.532 \\
0.3832 x\end{array}$ & $\begin{array}{c}0.503 \\
23.83 * * x\end{array}$ & $\begin{array}{c}0.564 \\
28.11^{* * *}\end{array}$ & $\begin{array}{l}0.456 \\
0.71 * * *\end{array}$ & $\begin{array}{l}0.573 \\
0.45\end{array}$ & 0.475 & $\begin{array}{l}0.360 \\
60100\end{array}$ & 0.428 \\
\hline
\end{tabular}


Beta Values; Level of significance: $*=\mathrm{p}<.05 ; * *=\mathrm{p}<.01 ; * * *=\mathrm{p}<.001$

Table 7-Continued

\begin{tabular}{|c|c|c|c|c|c|c|c|c|c|c|c|c|c|}
\hline VARIABLE & 㒯 & 总 & 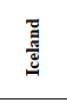 & 苞 & 胥 & 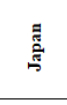 & 莡 & 总 & 总 & 言 & है & 惫 & 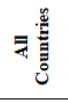 \\
\hline Interesting Work & $0.325^{* * z}$ & $0.152^{* *}$ & $0.387^{7 * z z}$ & $0.141^{*}$ & $0.313^{* z z}$ & $0.295^{* * *}$ & $0.279^{* * z}$ & $0.278^{* * z}$ & $0.305^{* z *}$ & $0.298^{* z *}$ & $0.369^{* * z}$ & $0.184^{* * z}$ & $0.287^{7 * * *}$ \\
\hline Job Autonomy & $0.093^{* *}$ & 0.003 & 0.067 & $0.262^{* * z}$ & 0.058 & 0.017 & 0.063 & 0.009 & -0.020 & -0.099 & 0.024 & 0.048 & $0.019^{* *}$ \\
\hline Help Others & -0.033 & 0.056 & -0.040 & 0.036 & 0.047 & -0.025 & 0.040 & 0.012 & -0.008 & -0.016 & 0.003 & 0.012 & $0.022^{* *}$ \\
\hline Job Useful to Society & -0.019 & $0.101^{*}$ & 0.045 & -0.031 & $0.095^{*}$ & $0.086^{*}$ & -0.041 & -0.006 & 0.065 & 0.074 & 0.001 & -0.013 & $0.037^{7 * * *}$ \\
\hline Job Security & $0.059^{*}$ & $0.204^{* s *}$ & 0.012 & -0.034 & 0.016 & 0.036 & 0.018 & 0.063 & 0.074 & 0.078 & $0.072^{*}$ & $0.117^{*}$ & $0.063^{* * *}$ \\
\hline Pay & $0.081^{*}$ & $0.162^{* *}$ & $0.102^{* *}$ & $-0.150^{*}$ & 0.028 & $0.136^{* * *}$ & $0.190^{* * * z}$ & $0.133^{*}$ & $0.143^{* *}$ & $0.173^{* *}$ & $0.182^{* * *}$ & 0.029 & $0.098^{* * *}$ \\
\hline Promotional Opportunities & 0.018 & -0.039 & $0.122^{* *}$ & $0.156^{*}$ & -0.009 & 0.011 & $0.094^{*}$ & 0.049 & 0.028 & 0.080 & $0.073^{*}$ & 0.044 & $0.057^{7 * * *}$ \\
\hline Physical Effort & 0.045 & -0.031 & -0.069 & -0.091 & -0.044 & -0.055 & -0.018 & -0.042 & 0.001 & 0.030 & $0.070^{*}$ & 0.056 & 0.005 \\
\hline Work Stress & $-0.183^{* * *}$ & -0.056 & $-0.088^{*}$ & 0.130 & -0.070 & $-0.182^{* * z}$ & $-0.10^{* * z}$ & -0.076 & $-0.093^{*}$ & $-0.118^{*}$ & $-0.084^{*}$ & $-0.109 *$ & $-0.086^{* * z}$ \\
\hline Relations with Coworkers & $0.075^{*}$ & -0.015 & $0.161^{* * z}$ & -0.104 & $0.122^{* * z}$ & $0.154^{* * *}$ & 0.064 & 0.055 & 0.085 & $0.142^{*}$ & $0.136^{* * *}$ & -0.003 & $0.085^{* * *}$ \\
\hline Relations with M & $0.176^{* * *}$ & $0.256^{* * *}$ & $0.246^{* * *}$ & $0.134^{*}$ & $0.221^{1 * * *}$ & $0.226^{* z *}$ & $0.231^{1 * *}$ & $0.248^{* * *}$ & $0.209^{* * z}$ & $0.265^{* * z}$ & $0.220^{* * *}$ & 0.075 & $0.225^{* * * *}$ \\
\hline Contact with Others & $0.066^{*}$ & 0.051 & -0.028 & -0.070 & 0.044 & 0.024 & -0.035 & -0.057 & -0.026 & 0.005 & 0.036 & 0.074 & 0.01 \\
\hline Discriminated Against at Work & $0.103^{* * z}$ & -0.067 & 0.031 & -0.013 & $0.075^{*}$ & 0.034 & 0.019 & 0.049 & 0.023 & -0.002 & -0.001 & $0.111^{1 *}$ & $0.037^{7 * z}$ \\
\hline Harassed at Work & -0.002 & $-0.100^{* *}$ & 0.022 & 0.041 & -0.012 & 0.013 & -0.010 & 0.015 & 0.004 & 0.107 & 0.007 & $0.096^{*}$ & $0.019^{* z *}$ \\
\hline Work from Home & 0.026 & 0.040 & $0.085^{*}$ & 0.013 & 0.058 & -0.024 & -0.064 & -0.053 & -0.014 & 0.011 & 0.000 & $0.101^{*}$ & 0.005 \\
\hline Work Weekends & -0.057 & -0.020 & $-0.089 *$ & $-0.129^{*}$ & -0.044 & -0.050 & -0.051 & -0.056 & $-0.098^{*}$ & 0.029 & $-0.089 g^{* *}$ & -0.003 & $-0.023^{3 * z}$ \\
\hline Schedule Flexibility & 0.044 & -0.054 & -0.007 & -0.003 & 0.028 & 0.048 & -0.005 & $-0.123^{*}$ & 0.066 & 0.058 & -0.017 & 0.059 & $0.014^{*}$ \\
\hline Flexibility to Deal with Family Matters & -0.060 & -0.035 & -0.027 & $-0.229^{* * z}$ & -0.009 & 0.000 & -0.045 & -0.066 & $-0.113^{*}$ & -0.054 & -0.060 & -0.003 & $-0.036^{6 * z}$ \\
\hline Work Interferes wi & $0.122^{2 * *}$ & $0.135^{* z}$ & $0.100^{* *}$ & $0.165^{*}$ & $0.154^{* z *}$ & 0.054 & $0.103^{* *}$ & $0.100^{*}$ & 0.035 & 0.013 & $0.110^{* z}$ & -0.036 & $0.097 * * *$ \\
\hline Gender & 0.003 & -0.048 & -0.004 & -0.034 & -0.051 & -0.007 & 0.041 & 0.025 & 0.040 & -0.049 & -0.007 & -0.017 & 0.005 \\
\hline Age & 0.041 & 0.041 & -0.001 & $-0.129^{*}$ & 0.003 & $0.075^{*}$ & $0.199 * z *$ & 0.031 & -0.041 & $0.196^{* *}$ & 0.033 & 0.055 & $0.033^{* * *}$ \\
\hline Education & -0.035 & -0.030 & -0.064 & $-0.169^{* *}$ & -0.020 & 0.006 & .0 .048 & 0.008 & -0.042 & -0.016 & -0.012 & -0.034 & $-0.045^{5 * z}$ \\
\hline Marital Status & -0.014 & -0.023 & -0.033 & 0.033 & -0.027 & -0.019 & 0.004 & -0.035 & $-0.134^{* *}$ & 0.002 & -0.035 & 0.006 & $-0.028^{8 z z}$ \\
\hline Size of Family & 0.020 & 0.027 & -0.019 & 0.021 & $0.073^{*}$ & -0.002 & -0.009 & -0.024 & 0.009 & 0.004 & -0.011 & 0.010 & -0.007 \\
\hline Work Hours & 0.034 & 0.040 & $-0.10^{* * *}$ & -0.093 & 0.073 & -0.054 & 0.052 & -0.020 & 0.032 & -0.012 & 0.001 & 0.017 & 0.006 \\
\hline Job Classification & 0.007 & $-0.109=$ & 0.080 & -0.091 & -0.001 & -0.022 & .0.039 & 0.031 & -0.042 & 0.031 & $0.082^{*}$ & $-0.123^{* z}$ & -0.009 \\
\hline Supervisory Status & 0.056 & 0.016 & 0.029 & 0.019 & -0.023 & -0.008 & 0.002 & 0.006 & -0.044 & 0.074 & 0.013 & 0.024 & -0.004 \\
\hline Employment Relationship & 0.002 & 0.042 & $0.110^{* *}$ & 0.070 & 0.017 & -0.032 & -0.052 & 0.000 & 0.092 & 0.042 & -0.016 & -0.072 & 0.008 \\
\hline Public/Private Organization & -0.009 & 0.001 & -0.061 & -0.095 & -0.016 & -0.023 & $-0.099^{*}$ & -0.054 & $-0.125^{* *}$ & 0.041 & -0.054 & -0.008 & $-0.022^{* z z}$ \\
\hline$N$ & & & & & & 550 & & & & & & & \\
\hline ADJ.R-SQUARED & 0.460 & 0.437 & 0.561 & 0.296 & 0.434 & 0.560 & 0.455 & 0.331 & 0.452 & 0.472 & 0.500 & 0.154 & 0.428 \\
\hline$F$ & $22.74^{* s *}$ & $11.77^{* s *}$ & $21.07 * * z$ & $5.39^{* * * *}$ & $16.32^{* s *}$ & $25.06^{* * *}$ & $15.66^{* * *}$ & $7.45^{* * *}$ & $10.59^{* * *}$ & $7.93^{* * *}$ & $22.42^{* * *}$ & $4.83^{* * z}$ & $483.58^{* * *}$ \\
\hline
\end{tabular}

Beta Values; Level of significance: $*=p<.05 ; * *=p<.01 ; * * *=p<.001$

\begin{tabular}{|c|c|c|c|c|c|c|c|c|c|c|c|c|c|}
\hline VARIABLE & 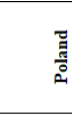 & 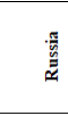 & 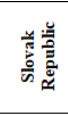 & 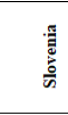 & 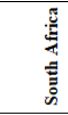 & 营 & 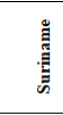 & 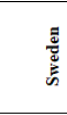 & 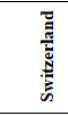 & 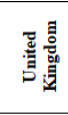 & 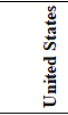 & 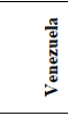 & 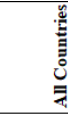 \\
\hline Interesting Work & $0.280^{* * z}$ & $0.165^{5 * z}$ & $0.202^{* * z}$ & $0.133^{* z}$ & $0.270^{* * * *}$ & $0.293^{* z * z}$ & $0.143^{*}$ & $0.419^{* * z}$ & $0.376^{* * *}$ & $0.363^{* * z}$ & $0.388^{* * *}$ & 0.083 & $0.287^{* * *}$ \\
\hline Job Autonomy & 0.041 & -0.013 & 0.030 & $0.142^{* * *}$ & 0.063 & $0.070^{*}$ & $.0 .117^{*}$ & 0.029 & 0.013 & 0.033 & -0.028 & 0.062 & $0.019^{* *}$ \\
\hline Help Others & 0.079 & 0.009 & 0.045 & $-0.122^{z}$ & -0.030 & -0.010 & -0.053 & $0.099^{*}$ & 0.036 & -0.002 & 0.023 & 0.055 & $0.022^{* *}$ \\
\hline Job Useful to Society & 0.033 & 0.034 & $0.132^{2 *}$ & 0.067 & -0.032 & 0.074 & 0.105 & -0.022 & 0.059 & -0.047 & 0.003 & 0.045 & $0.037^{* * z}$ \\
\hline Job Security & $0.166^{* * *}$ & 0.023 & $0.133^{* *}$ & $0.097 *$ & $0.156^{* * z}$ & 0.042 & $0.133^{*}$ & $0.078^{* *}$ & $0.076^{*}$ & 0.037 & $0.079^{* *}$ & -0.018 & $0.063^{* * z}$ \\
\hline Pay & 0.002 & $0.162^{2 * *}$ & -0.012 & $0.237^{7 * *}$ & 0.067 & $0.100^{* *}$ & 0.012 & 0.014 & 0.022 & $0.076^{*}$ & $0.102^{2 * z}$ & $0.118^{*}$ & $0.098^{* * z}$ \\
\hline Promotional Opportunities & -0.003 & $0.099 *$ & -0.072 & $0.115^{* *}$ & -0.036 & 0.067 & $0.144^{* z}$ & $0.110^{* *}$ & $0.131^{* * *}$ & $0.107^{7 * * *}$ & 0.057 & -0.035 & $0.057 * * *$ \\
\hline Physical Effort & $-0.108^{* *}$ & -0.024 & 0.025 & -0.004 & -0.005 & -0.037 & 0.020 & -0.057 & 0.056 & $0.097 * *$ & 0.000 & -0.044 & 0.005 \\
\hline Work Stress & -0.034 & $-0.105^{* *}$ & 0.060 & -0.029 & -0.061 & -0.035 & 0.018 & $-0.150^{* * z}$ & 0.000 & $-0.162^{2 * z}$ & $-0.103^{* * *}$ & -0.087 & $-0.086^{* * *}$ \\
\hline Relations with Cowork & 0.057 & $0.146^{* * *}$ & $0.123^{* *}$ & 0.068 & 0.009 & 0.062 & 0.055 & $0.137^{7 * * *}$ & $0.066^{*}$ & $0.090^{* *}$ & 0.024 & 0.023 & $0.085^{* * *}$ \\
\hline Relations with Management & $0.306^{* * z}$ & $0.159^{* * * *}$ & $0.346^{* * z}$ & $0.214^{* * *}$ & $0.293^{* * z}$ & $0.238^{* * *}$ & $0.190^{* z}$ & $0.183^{* * *}$ & $0.183^{* * z}$ & $0.290^{* * *}$ & $0.212^{* * z}$ & $0.287^{7 * z}$ & $0.225^{* * *}$ \\
\hline Contact with Others & -0.020 & 0.002 & $-0.10^{*}$ & -0.033 & 0.007 & 0.026 & -0.114 & -0.033 & -0.042 & -0.015 & $0.057^{*}$ & $0.152^{* *}$ & 0.01 \\
\hline Discriminated Against at Work & $0.103^{* *}$ & $0.100^{* *}$ & 0.032 & 0.070 & 0.021 & $0.103^{* *}$ & 0.042 & 0.036 & -0.024 & -0.036 & $0.119^{* * *}$ & $0.128^{*}$ & $0.037 * * z$ \\
\hline Harassed at Work & -0.002 & -0.007 & 0.041 & 0.059 & 0.005 & 0.017 & 0.043 & -0.002 & 0.008 & $0.061^{*}$ & 0.001 & 0.104 & $0.019^{* * z}$ \\
\hline Work from Home & -0.004 & -0.036 & -0.009 & -0.036 & -0.009 & 0.007 & -0.012 & 0.066 & -0.025 & 0.025 & -0.002 & -0.077 & 0.005 \\
\hline Work Weekends & 0.065 & 0.015 & -0.034 & 0.055 & -0.055 & -0.023 & -0.013 & -0.055 & 0.02 & -0.025 & -0.012 & 0.092 & $-0.023^{* * *}$ \\
\hline Schedule Flexibility & -0.001 & -0.022 & -0.023 & $-0.113^{z}$ & 0.021 & -0.033 & 0.075 & 0.043 & 0.067 & 0.019 & 0.034 & 0.017 & $0.014^{*}$ \\
\hline Flexibility to Deal with Family Matters & 0.003 & -0.008 & $-0.091^{*}$ & $-0.101^{*}$ & $-0.084^{*}$ & -0.050 & $-0.159^{* *}$ & -0.038 & -0.060 & -0.023 & -0.048 & 0.057 & $-0.036^{* * *}$ \\
\hline Work Interferes with Family & 0.027 & $0.109^{* z}$ & $0.11^{* *}$ & 0.070 & 0.067 & 0.050 & 0.077 & $0.074^{*}$ & $0.079 *$ & $0.0877^{* *}$ & $0.065^{*}$ & 0.073 & $0.097 * *$ \\
\hline Gender & -0.059 & -0.066 & 0.041 & 0.061 & 0.015 & $0.063^{*}$ & 0.010 & 0.002 & 0.025 & 0.053 & 0.020 & -0.048 & 0.005 \\
\hline Age & -0.030 & 0.022 & 0.01 & 0.0 & 0.034 & -0.007 & -0.002 & -0.001 & $0.124^{* *}$ & $0.094^{* *}$ & 0.049 & -0.013 & $0.033^{* * z}$ \\
\hline Education & -0.002 & -0.059 & $-0.093^{*}$ & -0.001 & -0.026 & -0.054 & -0.048 & -0.026 & -0.036 & -0.049 & $-0.117^{* * * *}$ & -0.075 & $-0.045^{* * z}$ \\
\hline Marital Status & -0.037 & -0.059 & -0.060 & -0.020 & -0.028 & -0.002 & $-0.114^{*}$ & 0.030 & 0.001 & -0.043 & $-0.069^{*}$ & -0.010 & $-0.028^{* * z}$ \\
\hline Size of Family & 0.041 & -0.028 & -0.069 & 0.013 & -0.037 & -0.020 & -0.043 & -0.059 & 0.041 & -0.007 & -0.015 & 0.006 & -0.007 \\
\hline Work Hours & 0.069 & -0.044 & 0.014 & 0.039 & 0.058 & 0.025 & $-0.100^{*}$ & 0.002 & 0.015 & 0.002 & $0.072^{* *}$ & -0.023 & 0.006 \\
\hline Job Classification & -0.004 & -0.042 & -0.066 & -0.023 & -0.036 & 0.048 & $-0.145^{*}$ & $0.078^{*}$ & 0.025 & -0.011 & 0.040 & -0.106 & -0.009 \\
\hline Supervisory Status & -0.016 & -0.065 & -0.071 & 0.040 & 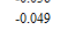 & 0.001 & 0.007 & 0.017 & 0.022 & 0.009 & 0.002 & -0.055 & -0.004 \\
\hline Employment $R e$ & -0.067 & 0.009 & -0.036 & -0.024 & -0.009 & -0.022 & -0.011 & 0.040 & -0.051 & 0.049 & 0.019 & -0.039 & 0.008 \\
\hline Public/Private Organization & 0.007 & -0.067 & $0.080^{*}$ & -0.080 & -0.048 & -0.044 & -0.032 & -0.046 & -0.029 & $-0.069^{*}$ & -0.035 & -0.062 & $-0.028^{* * z}$ \\
\hline & & & & & & & & & & & & 277 & 18,716 \\
\hline ADJ. R-SQUARED & 0.477 & 0.378 & 0.497 & 0.444 & 0.450 & 0.414 & 0.237 & 0.579 & 0.401 & 0.549 & 0.473 & 0.385 & 0.428 \\
\hline & $17.16^{* * *}$ & $13.93^{* * *}$ & $15.94^{* * * *}$ & $12.64^{* * * *}$ & 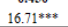 & $16.93^{* * *}$ & $5.12^{* s *}$ & $27.72^{2 * * *}$ & $16.69^{* * * *}$ & $31.89^{* * * *}$ & $26.06^{* * * *}$ & $6.06^{* * * *}$ & $483.58^{* * s *}-10$ \\
\hline
\end{tabular}

Beta Values; Level of significance: $*=p<.05 ; * *=p<.01 ; * * *=p<.001$

\section{Copyright Disclaimer}

Copyright for this article is retained by the author(s), with first publication rights granted to the journal.

This is an open-access article distributed under the terms and conditions of the Creative Commons Attribution license (http://creativecommons.org/licenses/by/4.0/). 